\title{
La mística agustiniana del amor en el Beato Alonso de Orozco
}

\section{INTRODUCCIÓN}

Ya hace un cuarto de siglo que el P. Lope Cilleruelo, antiguo director de nuestra Revista, se quejaba de la poca atención que había recibido de los estudiosos la Escuela Agustiniana de Salamanca, incluido uno de sus santos, o sea, el beato Alonso de Orozco. Decía nuestro autor así: "Hasta ahora, sólo Fray Luis de León ha tenido alguna suerte. Los demás Maestros de la Escuela, incluido el beato Orozco, continúan esperando en el silencio de los archivos y bibliotecas esa mano caritativa que sacuda las ramas y lance a volar a los pájaros ideales, dormidos en los pergaminos apolillados. La Escuela Agustiniana de Salamanca ha escrito una de las más bellas páginas de la cultura española. ¿No habrá llegado el día de que esa página, convenientemente aderezada e iluminada, sea puesta en la mano de los amantes de la teología y de la espiritualidad?" ${ }^{1 .}$

La celebración del cuarto centenario de la muerte de Alonso de Orozco es una buena ocasión que no conviene despreciar por lo que toca a este gran maestro de la espiritualidad y la mística española. La revista Estudio Agustiniano quiere ofrecer a sus lectores algo del rico tesoro espiritual elaborado por el beato Orozco de manera que su vida, su obra y su experiencia de Dios puedan llegar fácilmente a los hombres de nuestro tiempo.

En el presente artículo trataré de rastrear la mística del amor, recogida por la tradición agustiniana, tal como nos la muestra el beato Orozco principalmente en dos escritos, poco estudiados hasta el presente. Estos escritos son: Desposorio Espiritual, y Comentario al Cantar de los Cantares. El último

1. Cilleruelo, L., Prólogo a Turrado, A., Espiritualidad Agustiniana y Vida de Perfección. El ideal monástico Agustiniano en Santo Tomás de Villanueva. Religión y Cultura. Madrid 1966,6. 
escrito importante en torno al tema es la tesis doctoral de Ana J. Bulovas, $E l$ Amor divino en la obra del beato Alonso de Orozco. FUE, Madrid 1975. Se trata de un trabajo bien orientado y que nos hace excelentes indicaciones al respecto cuando dice: "La idea que inspira este trabajo es muy fácil de expresar: la vida espiritual del beato Orozco fue fundada sobre el amor divino, y era un ejemplo perfecto de un alma nutrida por la fuente y el sol del amor de Dios" ${ }^{2}$. Ciertamente la caridad es el alma de todo misticismo, pero tratándose de seguidores de san Agustín la centralidad del amor, sube de tono, si cabe expresarse así. Como dice el P. Bruno Ibeas: "Para san Agustín, una sola palabra comprende y define la ascética del cristianismo: Caritas. Bien es cierto que ella comprende y define, también, el Evangelio, como comprende y define a Dios, sobre todo en su manifestación temporal y soberana de la Historia" ${ }^{3}$. Antes se había dicho que los grados de la caridad son los grados de la perfección, como lo dice san Agustín: "La caridad incoada es perfección incoada, la caridad progresiva es perfección creciente, la caridad ardorosa es perfección intensa, la caridad perfecta es perfección definida" ${ }^{4}$. También nos avisaba el mismo autor que el amor en su fase más perfecta es unión con Cristo, y que como dice el mismo san Agustín: "Nos acercamos a Dios amando, no andando" 5 .

Contra la teoría de Julio Cejador de que el Audi Filia del Maestro Ávila es el punto de partida de la mística española, el P. Ibeas aduce que son anteriores varios escritos de la escuela agustiniana, incluidos algunos del beato Orozco $^{6}$. El mismo beato Orozco nos recuerda con Malón de Chaide que, como dijo san Agustín, cada uno es lo que es su amor, y la vida del hombre tiene el nivel vital, mayor o menor, peor o mejor, que el amor le da ${ }^{7}$. Ana J. Bulovas nos recordará un pasaje del Certamen del Amor santo del beato Orozco, que nos dice: "Es tan poderosa la fuerza del amor de Dios, que el alma enardecida de él, en este santo certamen, queda ya herida, ya presa, ya enferma, ya, finalmente, exánime, como muerta, en tal estado, cual la esposa de los Cantares..." ${ }^{8}$. Al ver este amor de Dios, también la persona humana, limitada, se siente atraída a amar de forma incondicional y hacerlo absolutamente. Así, como dice el Cantar de los Cantares, ponemos a Dios como sello de nuestro corazón y en nuestros brazos: Le amamos como vida de nuestra

2. Bulovas, A.J., El Amor divino en la obra del Beato Alonso de Orozco. Fundación Universitaria Española, Madrid 1975,5.

3. IBEAs, B., Los ascéticos agustinos españoles. España y América. Año 23, t. I (1925) 105.

4. Ib., 104: San Agustín, De natura et Gratia, LXX,84.

5. Ib., 103: San Agustín, Epístola 155,13.

6. Ib., 111 .

7. Ib., 179.

8. Citado por Bulovas, A.J., 71. 
vida y alma de nuestras obras. De manera que puede decir el alma con el Apóstol: Vivo yo, más ya no yo, vive en mí mi Salvador Jesucristo. Y así, se puede decir, verdaderamente, del Beato Orozco que "es el amor la substancia de su vida y de su obra" 9

Ana J. Bulovas no ha estudiado la obra: Desposorio Espiritual aunque lo cita en la comparación del Beato Orozco con Santa Teresa y con Fray Luis de Granada ${ }^{10}$. Por ello dedicaremos nuestro estudio fundamentalmente a este texto. Aunque nuestra autora no cita el Comentario al Cantar de los Cantares de Orozco, en cierta manera, se puede suplir por Certamen del amor Santo que que sí tiene en cuenta y puede valer como resumen del Comentario. Nosotros lo trataremos directamente, aunque con menos detalle. Por lo demás nuestra autora conoce perfectamente los diversos grados del camino espiritual y los describe muy bien valiéndose de las obras más importantes del beato Orozco.

En general, las obras del beato Alonso de Orozco, son una fuente muy rica de experiencia espiritual para todos los creyentes y, en particular, para las personas que tratan de vivir la vida religiosa. A todos se dirige nuestro autor para animarlos y estimularlos al amor de Dios y al amor de los demás.

\section{LA VIDA RELIGIOSA COMO RUMOR DE AMOR}

Entre los escritos sobre vida religiosa, de nuestro personaje, hay que conceder un lugar especial a la obrita titulada: Desposorio Espiritual, dirigida a una religiosa "hermana suya" con el fin de explicar el sentido de la profesión religiosa y de los votos, como una experiencia de Amor. Alonso de Orozco entiende la vida religiosa como una relación esponsal de Dios con la persona humana. Para ello parte del texto del profeta Oseas, 2,20, que dice: "Te desposaré conmigo en fidelidad, seré tu Esposo para siempre y sabrás que yo soy el Señor". La persona religiosa debe escuchar estas palabras con gran atención, pues indican su dignidad y su ser. Aunque han sido dichas primero a todo el pueblo de Dios, a la Iglesia, cuyo esposo es Cristo, según lo dice san Pablo en 2Cor 11,2: 'Os he desposado con un solo marido para presentaros a Cristo como casta virgen'. El amor esponsal se demuestra en que Cristo ha muerto en la cruz por su Esposa y ésta debe responder a su amor con una entrega incondicional.

San Agustín recoge ampliamente esta espiritualidad paulina y nos induce a ella en la carta 150 , un escrito muy corto, pero a la vez muy significativo. Es una carta dirigida a Proba (como la 130, sobre la oración) pero ahora con

9. Ib., 142.

10. Ib., 171 y 210 . 
motivo de la 'toma del velo' de una joven de la familia de Proba. Agustín dice a Proba que este hecho es mucho más importante que la nobleza de sangre de Proba, la cual ha dado cónsules al Imperio romano, pues aquí se trata de la unión con Cristo, con Dios, y no con un personaje humano; y de "un matrimonio que no tiene fin" ${ }^{11}$ se trata de la eternidad del Amor y del corazón. Dice el santo así: "Alégrese, pues, la muchacha, noble por su linaje y más noble por su santidad, porque ha de conseguir en los cielos una excelsa ventaja por su unión con Dios, mucho más que si propagase un sublime linaje por su unión con un hombre. Más generosidad ha mostrado la posteridad de Anicio al glorificar a tan ilustre familia con la abstención de las bodas que si la multiplicase con nuevos hijos; más al imitar en carne la vida de los ángeles que si de su carne aumentase el número de los mortales. Más grande y fecunda felicidad es crecer en el espíritu que soportar el embarazo del vientre, el candor del corazón que la leche del pecho, dar a luz cielo con las oraciones que dar a luz tierra de las entrañas" (Ib.). San Agustín nos detalla cada una de las funciones de la esposa: engendrar, dar a luz, amamantar. Este matrimonio con Dios es algo que todos pueden conseguir, mientras que la nobleza de sangre está reservada a unos pocos; pero quienes "desean unirse plenamente a Cristo, lo obtendrán al momento" ${ }^{12}$.

Esta espiritualidad es completamente actual. El concilio Vaticano II hacía referencia a ella al hablar de la castidad en el documento sobre la vida religiosa, Perfectae caritatis, 12 . El papa Juan Pablo II, en la Redemptionis Donum, n. 8, se refiere a esta experiencia cuando habla de alianza de amor esponsal y al amor 'esponsal' de Cristo. Y, en el número 11 de este mismo documento, después de citar 1Cor 7,28-40, o invitación de san Pablo a mantenerse célibe, afirma el Papa que: "Este consejo está dirigido de modo especial al amor del corazón humano. Pone más de relieve el carácter esponsal de

11. SAN Agustin, Obras completas, t. XI. a. Cartas, BAC, Madrid 1987, 3a, 386.

12. Ib., 387. P. Rousselot, estudioso de la mística española, en el siglo pasado, reclama para nuestros místicos la experiencia del amor divino como esencia de este misticismo, al que inspiran, según él y como puede verse fácilmente en el Beato Orozco, san Pablo y san Agustín. Esta mística española se desarrolla, frente a un catolicismo rígido e incluso inquisitorial (cf. pp. 443, 460,462 ), como una gran experiencia del cristianismo del amor y de la dulzura del amor de Dios en los místicos, según puede verse también en el mismo beato Orozco, aunque Rousselot ha preferido tratar a Malón de Chaide. También destaca Rousselot, la denuncia de los místicos contra la sociedad española de la época y sus abusos sociales: lujos, falta de justicia social y farsa de la caridad, en un catolicismo que no quiere cambiar de vicios. Esto nos los muestra el citado autor tanto a propósito de Alejo de Venegas (pp. 76-77) como en Malón de Chaide pp. 89 y 90. También defiende a nuestros místicos de la acusación de falta de Caridad y sentido social. Y entonces cita Rousselot a Santo Tomás de Villanueva, padre de los pobres, a san Juan de Dios, discípulo de Juan de Ávila, y fundador de una Orden de caridad (436-437). Lo mismo podría decirse del Beato Orozco y otros, aunque dicho autor no los tenga en cuenta. Cf. RousSELOT, P., Les Mystiques Espagnols. Didier et Cie., Paris 1869, $2^{\mathrm{a}}$. 
este amor" ${ }^{13}$. El último documento sobre formación para la vida religiosa, emanado de la Congregación de Religiosos, insiste también en esta experiencia de amor y en este rumor de Amor como elemento esencial de la vida religiosa tal como se expone en la Redemptionis Donum: "La profesión religiosa pone en el corazón de cada uno y de cada una (...) el amor del Padre, aquel amor que existe en el Corazón de Jesucristo, el Redentor del mundo. Es un amor que abarca al mundo y a todo lo que en él viene del Padre y que al mismo tiempo busca vencer todo lo que en el mundo no procede del Padre" (...). "Tal amor debe brotar (...) de la fuente misma de aquella particular consagración, que basada en el sacramento del santo bautismo, es el comienzo de (la) vida (del religioso) en Cristo y en la Iglesia, el comienzo de la nueva creación" ${ }^{14}$.

Otros textos semejantes, de la Redemptionis Donum, son: "La conciencia de pertenecer a Dios mismo en Jesucristo, Redentor y Esposo de la Iglesia, selle vuestros corazones (Cantar de los Cantares 8,6), todos vuestros pensamientos, palabras y obras, con el sello de la esposa bíblica" ${ }^{15}$.

Y poco más adelante se afirma que la consagración religiosa transforma el mundo por el amor y que "esta transformación es simultánea al amor que la llamada de Cristo infunde en el interior del hombre, con el amor que constituye la esencia misma de la consagración, la consagración del hombre y de la mujer a Dios en la profesión religiosa, sobre el fundamento de la consagración sacramental del bautismo" (Ib. 9). Esta espiritualidad del amor como esencia de la vida religiosa está ampliamente difundida en la espiritualidad actual; así, la opción de castidad en la vida religiosa define, de una vez por todas, que "para mí la vida es Cristo" (Filp 1,21) ${ }^{16}$.

Ante este rumor de amores, esencial, irá desgranando el beato Alonso de Orozco la explicación de la profesión religiosa. El Esposo ha sacado a su Esposa de Egipto, del mundo, y de la esclavitud del pecado y la llama a la

13. JUAN PABlo II, Redemptionis Donum, 11.

14. Congregación para los Institutos de vida Consagrada y las sociedades de VIDA APOstóliCA, Orientaciones sobre la formación en los Institutos Religiosos, 2.2.1990,11.

15. Redemptionis Donum, 8.

16. Bours, J., Kamphaus, F., Pasión por Dios. Celibato, pobreza y obediencia. Sal Terrae. Santander 1986, 31 y ss. En esta situación, se asume incondicionalmente una Alianza con Dios, unida también a la esencia del Cristianismo. J.M.R. Tillard lo expone así: "Esta aventura-mutua en la que Dios se vincula al hombre mediante una Alianza, se réaliza en dos planos estrechamente relacionados entre sí. El primero es el más misterioso, pero también el más radical. En él se verifica lo que el cristianismo considera su verdad más preciosa: Dios quiere hacer al hombre familiar suyo, introduciéndole en su vida más íntima, hasta el punto de no ser Dios, ya, simplemente, el Creador o el Redentor, sino Dios-con-nosotros, Dios-con-el-hombre. Esta familiaridad alcanza tal realismo, que un hijo de los hombres, Jesús, es asimismo, en la última radicalidad de su ser, Hijo de Dios": Thllard, J.M.R., Llamada de Cristo... llamadas del mundo. Una relectura de la vocación religiosa. Instituto Téológico de Vida Religiosa. Madrid 1979, 72. 
dulzura del amor de Dios que es la suprema belleza, el más noble de los nobles, el más sabio de los sabios, rey de reyes, señor de señores, creador de todos y sobremanera generoso: 'Para Esposa os quiere el que sólo es Esposo de las almas" ${ }^{17}$. Así de inconmensurable es el amor de Dios que rehace su imagen en el ser humano, débil y pecador, pero redimido por su Sangre: "y como me cuestan mucho estas almas, las amo mucho, y las sufro mucho: llámolas, ruégolas, que se vengan a mí: prométolas gran dignidad, que serán mis esposas, y que el desposorio será siempre sin fin: no como los otros desposorios, que son obligación de por vida, y muerto el uno de los desposados, el otro queda libre. Este Desposorio espiritual es tan fuerte, y tan perfecto, que tiene principio en esta vida, mas no tiene fin en la otra; antes allá se perfecciona, y fortalece, y en todo es más acabado" ${ }^{18}$. No hace falta decir que esta experiencia está muy próxima a la que antes hemos citado de san Agustín.

El mismo Alonso de Orozco comentando el Cantar de los Cantares nos encarece el gran amor de Cristo a la humanidad y la necesidad de correspondencia humana a este amor divino, dejándolo todo por Él. El beato Alonso de Orozco nos trae a la memoria el siguiente pasaje, al respecto: "Sanctus doctor Augustinus: 'Amore Deus venit ad homines, amore factus est homo, amore fuit comprehensus, flagellatus, spinis coronatus, et amore tandem in cruce obiit. Et hoc factum est propter filias Hierusalem, ob animas tenellas et delicatas, quippeque iaculo amoris Christi vulneratae, omnia mundi bona spernant, et flagrantissimam sponsi sui dilectionem contemplantes, dumtaxat Christo adhaerescant: necnon cum apostolo clament: Charitas Christi urget nos, estimantes quoniam si unus pro omnibus mortuus est, ergo omnes mortui sunt. Et iterum: Christo crucifixus sum cruci'. Faxit Deus optimus, ut in hoc ferculo existentes, sic charitatis sagitta sauciati, non nobis vivamus, sed ei, qui pro nobis in ara crucis mortuus est, et triumphator mortis surrexit" ${ }^{19}$.

Cristo nos entrega la riqueza sublime de su gracia y generosidad, su nobleza divina, en la entrega total de su vida para salvar a la esposa y purificarla y embellecerla, con el precio de su sangre, sin dejarle mancha ni arruga. Ése es el gran regalo de la gracia y de la fe con el anillo de la fidelidad para

17. Orozco, A. de, Desposorio Espiritual, en Orozco, Beato Alonso de, Obras Completas, tomo II, Madrid 1736, 435.

18. Ib., 436.

19. Orozco, Alonso de, Commentaria quaedam in Cantica Canticorum, nunc denuo ex Doctorum dictis congesta. Burgis, Apud Philippum Iuntam 1581, 129. Damos la trascripción moderna. El beato Orozco afirma que este libro del Cantar no se puede entender literalmente. Él traduce Cántico de Salomón, como Cántico del Amado. Y además dice que hay que entenderlo como los amores entre Dios y su pueblo, y entre Dios y el alma, y termina diciendo que en todo esto hay que ir al grano "Haud paleis victitemur, iumentorum in morem" (Ib., 2). 
una esponsalidad sin fin. La entrega del anillo, en la ceremonia de la profesión, como en el sacramento del matrimonio, significa esa unión incondicional y una fidelidad a toda prueba: en la salud y en la enfermedad, en la vida y en la muerte.

Luego pasa el beato Orozco a exponer las condiciones de vida que debe poseer la Esposa, según el ceremonial de la profesión religiosa. Para ello se remite a textos y costumbres del antiguo Testamento. Como es sabido Alonso de Orozco conoce muy bien el griego y el hebreo y eso le permite utilizar, con suma habilidad, los textos bíblicos. Así nos dice que según los mandatos de Dios, para que un israelita pudiera casarse con una extranjera, cautiva de guerra, se requerían cuatro condiciones que el beato refiere a la ceremonia de la profesión religiosa: cortarse el pelo, arreglarse las uñas, mudarse el traje y llorar un mes a sus padres. En efecto, cortar el cabello era costumbre al entrar en religión, por ser el pelo motivo de vanidad y, nos dice el Beato, en él quedó predicado y murió Absalón. El cabello es un elemento esencial en el enamoramiento, y el alma consagrada no puede tener dos amores, como recordará también el Cántico espiritual de san Juan de la Cruz. Además el cuidado del cabello da mucho que hacer, especialmente a la mujer, y es motivo de 'cuidados superfluos' y mundanos. Los penitentes, como Job, se raen el pelo para orar y dejar otros cuidados, o ponerse al servicio de Jesús. Como la Magdalena: “A los pies de Cristo pone la Religiosa sus cabellos, cuando los huella por su servicio, y amor, y cuando nada se le da de parecer bien a los ojos de otros. Mas tenga aviso de Esposa de Cristo, no torne a crecer el cabello, para su muerte, como leemos de Sansón, que a sí mismo se mató. Guarde el Señor a sus siervas de esta vanidad, pues ya una vez la dejaron por Dios" ${ }^{20}$.

Gusta mucho el Beato Orozco de estos ejemplos plásticos, y en esto demuestra su gran estilo y habilidad oratoria y literaria. Así, cuando hable de los religiosos nuevos dirá que hay que ponerles un palo para que no se tuerzan pero que ese palo ha de ser el Evangelio. Lo mismo en la Reina de Saba nos habla del reloj como gran invención del hombre que mide el tiempo. A la vez gusta de citar a los grandes pensadores de la antigüedad, lo mismo que a los santos Padres, y llama al hombre 'un milagro en el mundo', lo que nos demuestra también su gran humanidad. Pues bien, por lo que respecta a este signo externo del cabello ha adquirido diversos sentidos en la vida humana y religiosa a lo largo de los tiempos. El Beato explica la ceremonia de cortarse el pelo como signo de consagración. Eso no obsta para que en la ley del nazareato de Números 6,5 se diga: "El que se consagró a

20. Desposorio, 436. 
Yahvé, será santo y dejará libremente crecer su cabellera". San Pablo a su vez, considera lo contrario, que es un signo más religioso el pelo cortado. En las religiones antiguas también se encuentran mezcladas ambas costumbres: la de cortarse el pelo y la de dejarlo crecer libremente por motivos religiosos. En el mundo antiguo, los filósofos cínicos y en el mundo actual en el movimiento hippy se dejó de cortar el pelo como forma de protesta social. Ahora parece que se va en otro sentido. San Agustín adopta dos posturas aparentemente contrapuestas. En el De Opere Monachorum condena duramente a los monjes 'golondrinas', monjes, tan holgazanes que ni se cortaban el pelo. El santo cita a san Pablo en su favor: 'es una ignominia para el varón quedar intonso'. Pero también ve san Agustín que la calidad del monje no depende del cabello: "No quiero extenderme, sobre este vicio por respeto a algunos hermanos intonsos, cuya conducta venero, casi en todo, fuera de eso" ${ }^{21}$. E1 asunto creaba 'disputas amargas' y harto peligrosas, y san Agustín teme que los monjes haraganes utilicen este pretexto "para seducir a los hombres tanto más fácilmente cuanto que ven entre ellos a otros monjes a quienes honramos con merecida obligación de caridad cristiana por sus restantes condiciones buenas. Si después de esta amonestación, o más bien súplica mía, creen que deben perseverar en ese daño, nada haré sino lamentarlo y gemir. Me basta que lo sepan; si son siervos de Dios me compadecerán. Si no me compadecen, no quiero decir algo más duro" ${ }^{22}$.

Unos años más tarde, en La Ciudad de Dios, Agustín se muestra aún más cauto en esta cuestión de las formas externas, en la vida de los creyentes, cuando habla de la conversión de los filósofos al cristianismo. No se da importancia al aspecto exterior del hombre en la ciudad de Dios, sino a la honradez y la honestidad: "No tiene importancia en esta ciudad, al abrazar la fe que nos lleva a Dios, se adopte un género de vida u otro (quo habitu vel more vivendi), con tal de que no sean contrarios a los preceptos divinos. Incluso a los mismos filósofos, cuando se hacen cristianos, no se les imponen unas maneras de comportarse o de vivir (non habitum vel consuetidinem victus) que ningún impedimento suponen para la religión; se les obliga únicamente a cambiar sus falsas creencias. Aquel distintivo que Varrón señaló característico de los cínicos, si no lleva consigo alguna torpeza o algún desarreglo, no le preocupa en absoluto" ${ }^{23}$. Como ha explicado Martín Hengel en Seguimiento y carisma algunos confundían ciertos predicadores ambulantes

21. San Agustín, Obras completas, t. XII, Madrid, cap. 31.

22. Ib., cap. 33.

23. San Agustín, La Ciudad de Dios, XIX, 19. 
de grupos filosóficos, con los predicadores cristianos, lo que nos indica el estado de la situación en aquel tiempo.

Dejadas de lado las cuestiones anecdóticas, lo importante es que el que coma lo haga por el Señor, y el que no coma lo haga también para gloria del Señor, para que todos glorifiquen y se glorían en el Señor. Lo dicho del pelo, se dice de las uñas o de cualquier otro cuidado corporal sujeto a los usos y costumbres de los tiempos y los hombres. También ha sido muy frecuente dejarse crecer las uñas, como símbolo de sabiduría o de dedicación religiosa, como aún ocurre entre los orientales. Lo que importa son los motivos y los fines. Pero las uñas también dan mucho que hacer a algunas mujeres, les hacen perder tiempo en su cuidado y cuidan su vanidad. Por eso el Beato Orozco advierte de cortarse las uñas a las personas religiosas, pero sobre todo han de cuidar de caer en los vicios que simbolizan como son: la murmuración, el odio, la venganza y las peleas de convento que desdicen gravemente de quienes tienen por Esposo a aquel que nos dijo: "Aprended de mí que soy manso y humilde de corazón" (Mt 11,29) Cristo, el Cordero de Dios nos quiere mansos y humildes, nos advierte el Beato.

Del mismo modo la persona religiosa ha de vestir el cuerpo de la nueva vestidura para que se vista el alma de virtudes nuevas y del hombre nuevo.

Finalmente explica el Beato que se ha de llorar a los propios padres, en el sentido de que, en la vida religiosa, ya no se debe "hablar ni pensar en linaje, que ya todo murió: y cosa es muy vana, y de gran abatimiento en la Religión, tratar de otra sangre, sino de la de Cristo, de otro linaje, sino del que tenemos heredado por la gracia divina, siendo hijos de Dios, según nos certifica san Juan; y si otra cosa hay, la tal no se tenga por Monja, sino por mundana, no por Esposa de Cristo, sino hija de vanidad, y esposa del soberbio rey de los soberbios Satanás" ${ }^{24}$.

La vida religiosa es pura vida de fe que "obra con amor de caridad, mediante la cual todo se puede, y con todo sale el alma" ${ }^{25}$. Así es como se sigue a Cristo que venció las riquezas, la sensualidad y el dominio del mundo, para encaminarnos a su Reino, con paciencia, como el labrador soporta el invierno y el verano para alcanzar su cosecha. "Así dice san Pablo: Hermanos, teniendo vuestro fruto con santificación, sea vuestro fin la vida eterna" (Rom 6). Los medios para este fin, son de quien luego diremos. "Vos, hermana, como Esposa leal de Cristo, velad siempre, y orad, sirviendo con amor a tal Esposo, y Salvador nuestro" ${ }^{26}$.

\footnotetext{
24. Desposorio, 437.

25. Ib., 437.

26. 437.
} 
Comentando brevemente la regla de san Agustín nos recuerda el Beato el mismo fin esencial de la vida religiosa, pues Jesús nos dio un mandamiento fundamental "que nos amemos unos a otros como él nos amó en Dios y por Dios. Este mismo censo y tributo nos impone nuestro Padre cuando dice que ante todas las cosas amemos a Dios, y al prójimo" ${ }^{27}$. Y añade que por la unidad del corazón y la caridad, Dios está en la comunidad. Como resumiendo esta espiritualidad nos avisa el principio agustiniano: 'ama y haz lo que quieras', puesto que de la raíz del amor nada puede nacer que no sea el bien y cosas buenas. El mismo san Agustín en el De moribus Ecclesiae Catholicae declara el sentido de la vida de los monjes bajo el signo del amor, de esta manera: "La caridad es lo que principalmente observan: a la caridad adaptan el alimento, a la caridad la conversación, a la caridad el vestido, a la caridad el semblante, en sola la caridad se reúnen y conspiran; el violarla lo tienen por gran pecado, como ofensa de Dios; si algo la resiste lo corrigen y deshechan, si algo la ofende no permiten que dure un solo día. Saben que de tal suerte la tienen recomendada Cristo y los apóstoles, que si ella sola falta, todas las demás obras son vanas, si ella subsiste, todas las obras son cumplidas" 28 .

Nos advierte el beato Alonso de Orozco que quien viene a la vida religiosa debe tener como tesoro supremo a Dios, por encima de todo, para lo cual no le faltará su gracia: "el que viene a tomar el hábito, venga determinado a servir a Dios, y con tal deseo que todo lo desampara por Jesucristo, y no por otro respeto, dado que antes haya sido gran pecador" ${ }^{29}$. Por otra parte nuestro hermano se muestra muy humano cuando dice, en relación a la llamada vocacional: "Poco va en la manera de ser llamado, si el que viene a tomar el hábito persevera en la vocación a que Dios le llamó: porque Dios más mira a los fines de nuestra obra, que a la causa de donde nos movimos a dejar el mundo" ${ }^{30}$.

Como ya hemos apuntado, gusta el Beato mucho de usar los ejemplos de la vida ordinaria, de los nuevos inventos y del constante apoyo bíblico. Así dice que al que comienza la vida religiosa conviene darle algún ánimo y apoyo como el palo que se pone al arbolito plantado nuevo, pero advierte que el palo que se ha de dar al religioso es precisamente la guía segura del Evangelio para que no se tuerza el novicio sino que vaya bien orientado: "El

27. Orozco, A. de, Breve declaración de la Regla de Nuestro Padre San Agustín. Amigos del País, Manila 1881, 45-46.

28. SAn Agustín, De moribus Ecclesiae Catholicae, 33, 73.

29. Orozco, A. de, "Instrucción de Religiosos", en Crónica de la Orden, Sevilla 1551, cap. I, (50) 59 vuelta col. 2.

30. Ib., cap. I, $59 \mathrm{v}$. y $60 \mathrm{col} .1$. 
palo a que se ha de arrimar el buen cristiano es el santo Evangelio y ley divina por la cual así como por una regla que jamás se puede torcer ha de medir toda su vida" ${ }^{31}$.

Nuestro autor insiste sin descanso en la vida religiosa como vida del amor. Comentando el salmo 132: "Mirad que es cosa buena y alegre morar los hermanos en comunidad", se nos dice "que seamos hermanos tan amados, que nuestro amor en Dios sea uno, nuestro deseo uno y nuestra vida en todo tan concertada que en nada haya disensiones ni turbación" ${ }^{32}$. Y que nuestro corazón sea uno y una nuestra alma en Dios, pues uno es nuestro Dios y una nuestra fe. Esta unidad admira incluso a los infieles y a los que no creen en Dios ni conocen a Jesucristo, nos dice el Beato, al remitirnos, una vez más a san Agustín: "Voz dulce es la que aquí se nos dice, según nuestro Padre afirma declarando este salmo: Armonía celestial es y no inventada en la tierra, sonido de trompeta admirable es que bastó a juntar muchos ejércitos de monasterios y órdenes" 33. Como nos había dicho san Lucas: andaban a uno y trataban a Dios en unidad sin tener nada propio. Y lo que más es: que tenían un ánima y un corazón de Dios. "Los cuerpos muchos eran, más el corazón uno era, el espíritu no más de uno, el amor y caridad una, que los hacía a todos unos" ${ }^{34}$. Y así fundaron sus Órdenes, nos dice el Beato, san Basilio, san Agustín, san Francisco, santo Domingo y todas las demás órdenes. Todos siguieron esta vida y comunidad apostólica que desde la vida común nos enseña a amar a Dios y nos anticipa la vida del cielo, la vida divina que ya se nos da al presente.

Alonso de Orozco, en absoluto, nos quiere decir que no habrá dificultades ni tentaciones. Cuando el hombre se libera, como los israelitas de Egipto, es cuando más será asaltado. San Agustín nos anima al decirnos que el enemigo ya ha sido 'vencido' por Cristo, pero no hay que olvidar que la vida es lucha y tentación en esta tierra y "que no hay mayor tentación para el amigo de Dios que no ser tentado" ${ }^{35}$. Esta vida es siempre tempestad y tribulación donde se ejerce la fe, la esperanza y la caridad, si no olvidamos la oración y sabemos mirarnos en el espejo de la Escritura Santa. La tentación mayor, nos dice el beato Alonso de Orozco, es pensar que el religioso podría hacer algo mejor en el mundo, fuera de la vida religiosa. Así se presenta Satanás como ángel de luz. Todavía hoy muchos abandonan la vocación religiosa pensando que harán mucho más fuera de ella. Pero nos advierte el

31. Ib. del Prólogo 59, col. 1.

32. Ib., cap. 5. 61v. col. 2 .

33. Ib., cap. 5, 62 col. 1 .

34. Ib., cap. 5, 62, col. 1 .

35. Ib., cap. 6, 63, col. 1 . 
Beato: "Cosa grande es dar plata y oro por Dios, mas mayor es darse a sí mismo a Jesucristo" ${ }^{36}$. Mejor es María que Marta aunque Marta se vea más. $Y$ es necesario vivir antes la vida en la comunidad que la vida en el desierto, porque, además, el buen religioso encuentra el desierto en su propia comunidad. Por eso dijo el Filósofo: "El que no comunica con otros, o es bruto animal o es Dios. Quiere decir: que el tal, o lo hace de rústico y salvaje o porque es hombre divino y muy dado a Dios, por quien deja toda compañía y conversación ${ }^{37}$.

Como toda la vida religiosa, la tarea de la formación para la misma es también obra de amor y de misericordia, de corazón compasivo; así han de ser los maestros de la formación: "Gran caridad es menester que tenga el maestro de los mancebos, para que enferme con los enfermos compadeciéndose de ellos" ${ }^{38}$. Por eso no ha de ser el formador precipitado ni descuidado, ha de respetar el tiempo y caminar con el que comienza, y así "el maestro que sea sabio, virtuoso y en todo varón perfecto" 39

La suavidad de Dios, amador dulcísimo, debe ser el gran gozo del religioso, la vida de su vida y el amor de su amor que le lleva a la felicidad, mientras quien ama el mal del mundo es un muerto que ni ve ni oye ni entiende aunque en apariencia viva, nos dice el beato Alonso de Orozco ${ }^{40}$.

Todo esto no puede ocurrir sin humildad. Esta virtud es de gran valor para beato Alonso de Orozco; muy en línea, una vez más, de la tradición agustiniana considera la humildad como la virtud más excelente, después de las tres teologales: "La humildad es la zanja del edificio espiritual, y el fundamento sin el cual las otras virtudes nada valen, y caen muy aina como edificio sin cimiento" (...) "Por eso decía nuestro Padre san Agustín: si piensas hacer alguna torre muy alta, primero trata y piensa del fundamento que de las paredes. Lo contrario sería edificar al revés y sin provecho" ${ }^{41}$. La humildad es el cimiento de las otras virtudes. Es una virtud del alma y sus grados son someterse a los superiores, a los iguales y a los inferiores. Cristo estimó en mucho esta virtud nos dice el Beato. Y su encarnación y abajamiento es gran lección de amor a la misma, pues siendo muy superior a todos se hizo 'uno de tantos'. La falta de humildad crea gran desasosiego en el religioso y en la comunidad, al no ocuparse en la experiencia misteriosa y profunda del amor santo sino en el combate mundano por los bienes de esta tierra. En

36. Ib., cap. $7,63 \mathrm{v}$. col. 2 .

37. Ib., cap. 7, 64, col. 2.

38. Ib., cap. $8,64 \mathrm{v}$., col. 1 .

39. Ib., cap. 8,65 , col. 2 .

40. Ib., cap. 9,55 v. col. 1 .

41. Ib., cap. $10,56 \mathrm{v}$. col. 1 y 2 . 
cambio la vida religiosa es milicia escondida del amor santo embriagada de la caridad en este mundo: ¡Admírate! Este certamen del amor de Dios no se celebra a la luz del día, sino de noche, tal vez porque la fe es sombra santa, de la cual dice la Esposa: me senté a la sombra de aquel que habia deseado, y su fruto, dulce a mi garganta. He ahí a Jesucristo, árbol de la vida, cuya sombra protege a nosotros, los fieles en este destierro donde, creyendo en él y amándole, nos libramos de innumerables errores. Su fruto es vida, y su muerte nos es tan suave y al paladar de nuestra alma tan dulce que la Pasión de Jesucristo y su preciosa vida son más suaves que toda miel. Además, la fe es la sombra santa del Esposo, con cuya virtud, libres del ardor de toda concupiscencia, descansamos tranquilos y seguros, inflamados por el deseo de los bienes eternos" 42 .

Solamente en la vida eterna el amor nos será plenamente revelado sin temor ni sombra alguna. Pero entretanto podemos adentrarnos en el corazón de Cristo encendido en el fuego del amor y la caridad, pues como dijo la Esposa: "Me introdujo en la bodega del vino; ordenó en mí la caridad (Cantar de los Cantares 2,4). ¡Oh admirable orden de la caridad, sin la cual todas las potencias y afectos del alma quedan desordenados, pobres y viles y deformes sobre toda deformidad! El bellísimo orden de la caridad pide que todo lo amemos por Dios y en Dios; mas a Dios, como sumo bien, por sí mismo. He ahí la escuela de la celestial filosofía, y la cátedra admirable donde Cristo Jesús, virtud y sabiduría de Dios, como dice san Pablo enseña superabundantemente a sus discípulos esta mística teología. ¿Cuál es la regia bodega, riquísima en suave y purísimo vino, sino su corazón ardiendo en fuego de amor, y por no decir horno encendido en el que, durante la cena estuvo recostado Juan, su amado discípulo, y tres jóvenes ilesos alaban a Dios: memoria, entendimiento y voluntad, engrandeciendo con dulce y armoniosa voz al Señor, y diciendo: Bendecid todas las obras del Señor al Señor; alabadle y ensalzadle eternamente? (Daniel 3,57). Cuantas veces contemplo el sacratísimo corazón de Jesús, cuantas veces considero sus paternales entrañas llenas de misericordia, miro las encendidas llamas de amor que tocan el cielo, y me parece oír de su divina boca estas ardientes palabras: Vine a arrojar fuego a la tierra, y ¿qué otra cosa deseo sino que arda? (Lucas 12,49)" 43.

$\mathrm{El}$ amor todo lo une, unifica al hombre consigo mismo y con los otros seres humanos, pero sobre todo nos une con Dios. Como dice san Bernardo

42. OROzCO, A. DE, Certamen del Amor Santo del beato Alonso de Orozco, del Orden de Ermitaños de san Agustín, en el que debe ejercitarse todo religioso para que pueda gustar la dulzura de la caridad. Trad. castellana del P. Pedro Lozano. Gabriel López del Horno, Madrid $1914,306$.

43. Ib., 298-299, y 301. 
(Sermón 71 sobre el Cantar de los Cantares): "El hombre y Dios no puede decirse que son uno, una sola cosa, porque no tienen una misma substancia o naturaleza, mas pueden decirse un espíritu cierta y verdaderamente si se unen con el lazo del amor, la cual unidad la hace, no la unión de lo esencial, sino la conformidad de voluntades" ${ }^{44}$. Así el que ama a Dios ama la vida y quien ama al pecado se odia a sí mismo, odia la vida y aborrece la humanidad, como dice el salmo: "El que ama la iniquidad aborrece su alma. No sin razón dijo un pagano: Las inclinaciones amistosas hacia otro (Aristóteles, Ethic. lib. 9, c. 4 y 8 al principio) proceden de aquellas que a sí mismo se tienen. Como si dijera, tomándolo del Eclesiástico (14,5): Quien es cruel para sí ¿para quién ha de ser beneficioso y compasivo? El que mata a su alma, ¿de quién se compadecerá para librarle del peligro de muerte espiritual?" ${ }^{45}$. También Malón de Chaide nos hace esta misma reflexión en su Conversión de la Magdalena. Es el amor de Dios derramado por el Espíritu Santo en nuestros corazones el que nos lleva a amarnos realmente a nosotros mismos y a amar de verdad a nuestro prójimo ${ }^{46}$. El amor es el mandato distintivo de Jesús a sus discípulos: "Ya lo ves, hermano: no os juzgarán, dice Jesucristo, los hombres discípulos míos, porque hagáis milagros, reveléis celestiales misterios, ayunéis frecuentemente y déis limosnas a los pobres, sino cuando se persuadan que os amáis los unos a los otros, llevando con paciencia los sufrimientos y trabajos. Solamente el amor al prójimo es, pues, la señal eficaz e inequívoca de los verdaderos discípulos de Jesús" ${ }^{47}$. Ambos amores proceden del mismo Dios, incluso el amor a los enemigos que tan difícil resulta. Pero el amor todo lo puede. Como dice san Agustín: "El amor, todo lo cruel, dificil y repugnante lo hace fácil y casi nulo". Y él mismo: "Sólo el amor se avergüenza hasta del nombre dificultad" "48.

El amor lleva al perdón y vence al mal con el bien como también se ve ya en el Antiguo Testamento (Reyes 26,21). El Amor nos hace eternos porque la caridad permanece para siempre, pues el amor nunca muere, como dice san Pablo (1 Cor 13,8) y repite san Agustín. Nuestro amor a Dios ha de ser incondicional como lo es el amor de Dios al hombre, pues por su excesiva caridad, con que nos amó, envió a su Hijo (Ef 2,4). Como dice "san Bernardo: Dios ha de amarse por ser Dios; y el modo de amarle, es amarle sin modo, esto es, sin limitación alguna, por esto no puede haber exceso en

44. Ib., 467, nota 13.

45. Ib., 314-315.

46. Ib., 317.

47. Ib., 319-320.

48. Ib., 323. 
amarle" ${ }^{49}$. No debe darnos miedo la dificultad de este gran amor pues como nos dice san Agustín: "Nada hay difícil para el amante, antes bien, todas las cosas son suaves y están llenas de dulzura para los que aman a Dios" ${ }^{50}$.

El amor es todopoderoso, de modo que Dios mismo se deja vencer por el amor. Por él abandonó su condición divina en el cielo para salvarnos a todos los hombres. San Bernardo nos lo dice así (Ser 64, n. 10, del Cantar de los Cantares): “ $\mathrm{O}$ Oh suavidad! !oh fuerza del amor! ¿Es posible que el Altísimo, el superior de todo, se haya hecho uno para todos? ¿Quién ha obrado esto? El amor, olvidado de su dignidad, rico en grandeza, en el afecto poderoso, eficaz en el consejo. ¿Qué cosa más violenta? El amor triunfa de Dios. Sin embargo ¿qué cosa más voluntaria? Es el amor" ${ }^{51}$. El amor nos lleva a la unidad con Dios, con nosotros mismos, y con los demás, por eso dice san Dionisio que la vida religiosa nos une totalmente en un solo Espíritu, Señor y dador de vida: "Los monjes, así llamados por su individual y singular manera de vida, por la contemplación santa de las cosas invisibles, son promovidos a la indivisa unidad y perfección tan grata a los ojos de Dios" ${ }^{2}$.

Dios está siempre cerca de nosotros, pues en él 'vivimos, nos movemos y existimos', y nos da la verdadera felicidad: "Cree, hermano, al experimentado: No hay en esta vida gozo verdadero, si no lo causa Dios. Este gozo nace de la buena obra y sincera caridad; todas las demás cosas, por más felices y risueñas que aparezcan, encierran, más que dulzura, acíbar, para el espíritu" ${ }^{53}$. Pero lo que es obra de amor es siempre grato sobremanera. Y el Beato propone cuatro grados de la caridad, especialmente para la vida religiosa: la herida de amor, la prisión de amor, la enfermedad de amor y la muerte por amor; en ésta el religioso muere a sí mismo por el amor que ama a Cristo, puesto que Cristo ha muerto por él. Con sus mismas palabras: "Dichoso, bienaventurado el religioso que en este certamen del amor, no sólo salió herido, sino que mereció ser prisionero y llevado cautivo. Diré más: felicísimo aquel que en semejante lucha del amor divino haya enfermado y quedado exánime, como muerto. He aquí indicadas cuatro grandes señales de caridad" ${ }^{54}$.

49. Ib., 339 y 480 .

50. Ib., 342 y en p. 483, nota 45 cita a san Agustín en el De Moribus Ecclesiae Catholicae. cap. 22,41: "Nada hay, sin embargo, tan duro y fuerte, que no lo venza el fuego del amor, con el cual el alma volará a Dios, y libre de todo tormento, con admiración de todos, se remontará sobre todo lo terreno y visible en las alas bellísimas y santísimas en que se apoya el casto amor para el ósculo santo a Dios".

51. Ib., 485 , nota 6 .

52. Ib., 349.

53. Ib., 362.

54. Ib., 365. 
Así la persona religiosa queda herida por el amor, pues Dios que es amor lanza su dardo de amor a la humanidad y en especial a cada persona religiosa que se pone a su alcance y le entrega su corazón y su vida. Así dice san Agustín: "Asaeteaste tú, Señor, con tu amor nuestro corazón, y como agudas saetas llevamos tus palabras atravesadas en nuestras entrañas" ${ }^{55}$. Así es cómo los discípulos de Emaús sentían arder su corazón por el camino con Jesús, y eso es lo que dice el Cantar de los Cantares $(4,9)$ : Heriste mi corazón, hermana mía, esposa; heriste mi corazón. Y esta herida no se da en la mano o en el pie "sino en el corazón, porque la caridad, que por naturaleza tiene su morada en el corazón, arroja de sí ardentísimos afectos que, a manera de saetas, no ya tocan, mas hieren el corazón divino; y así este dardo salió del corazón y en el corazón reposa. El amor de Dios procede del corazón del hombre, y penetrando los cielos, halla la paz en el corazón de Dios, no buscando dones, sino al mismo Dios. Ama desinteresadamente al que de la misma suerte nos amó" ${ }^{56}$. El Padre Malón de Chaide nos recuerda que cada uno es lo que es su amor, así como dice san Agustín que cada uno es lo que ama: "si tierra amas, tierra eres; si cielo amas, cielo eres; y si a Dios amas, Dios eres', conforme a lo que dice el apóstol: qui adhaeret Deo, unus spiritus est cum eo" ${ }^{57}$. Del mismo modo nos recuerda el P. Malón de Chaide que la herida de amor transforma al hombre en Dios: "heridos y rayados con aquella inmensa fuerza del amado eterno, Dios, se parecen a otra fragua de amor divino, y cada uno parece un Dios digno de ser amado. Por eso, mirándose unos a otros, y viendo en cada uno aquel Dios, que dulcemente aman, no pueden dejar de amarse entre sí. ¡Oh, ciudad enamorada, quién se viese en ti!" 58.

Igual que el beato Orozco nos invita a amar desinteresadamente y a no buscar tanto los dones de Dios como a Dios mismo, nos dice el P. Malón de Chaide: "Pida sabiduría el necio, pídate honra el ambicioso, soberbio, pida hacienda el avariento cruel, pida deleites el hombre sensual, que yo, Señor, tu amor te pido. Nolo tua sed te, dice san Agustín. No quiero, Señor, a tus cosas, sino a ti. Si tu amor me niegas a ti te me niegas, y si tu amor me das, a ti te me das. Todas las otras cosas que tienes, comunes son a los buenos y a los malos; pero tu amor sólo es para los buenos, sólo para tus amigos. Con el amor lo tengo todo, sin el amor no tengo nada ${ }^{59}$.

55. Ib., 367-368.

56. Ib., 370.

57. MAlón DE ChAide, P., La conversión de la Magdalena, I y II. Clásicos Castellanos. Espasa-Calpe, Madrid 1947, $2^{\text {a }}$ Prólogo y notas del P. Félix García, t. I, 54. Como se sabe hoy se tiende a escribir Malón de Echaide, pero nosotros conservamos la grafía antigua.

58. Ib.,I, 57.

59. Ib., I, 67. 
Es de notar que Alonso de Orozco también dice cosas muy semejantes a lo que nos dice Malón de Chaide cuando se refiere, de pasada, al amor mundano: “¡Oh cuán útil al par que bello es ser llagado de la caridad! Verás algunos, enfermos, heridos por el dardo del amor nefando; otros, destrozados por el acero de las riquezas. ¡Oh y cuán grande es, en el mundo, el número de los necios! Tú, hermano, ofrécete espontáneamente y de buen grado a servir de blanco al abrasado dardo de la caridad, si quieres triunfar en este admirable certamente. ¡Oh cuán esforzado flechero es Dios que nunca hierra, siempre da en el blanco" ${ }^{60}$.

Respecto a los que han quedado prendados y prendidos en esta herida del amor de Dios cita el beato Orozco a Orígenes, en su comentario al Cantar, libro I, y con referencia a este verso de la herida de amor dice: "Yo creo que si alguna vez llegaren a este grado, no deben ya andar, ni correr, sino estar junto a Cristo como ligadas por el vínculo del amor, ni haya en ellas en adelante movilidad alguna más sean con él uno y mismo espíritu" ${ }^{61}$. También Alonso de Orozco cita el texto paulino que trae Malón de Chaide, como hemos visto en este mismo párrafo inmediatamente anterior. Y también, después de alabar la fuerza unitiva del amor con palabras de san Dionisio, dice: "Está muy conforme con esta sentencia ('el amor es virtud unitiva') aquello de san Pablo: 'El que está unido al Señor, es un espíritu con él' $(1$ Cor 6,17)" 62 .

También nos recuerda el Beato, con el Cantar de los Cantares 8,6, que "el amor es más fuerte que la muerte" ${ }^{63}$. Así, el amor todo lo puede y lleva al alma cautiva. Y Malón de Chaide comenta este pasaje así: "Fortis est ut mors dilectio. El amor es fuerte como la muerte, y aún mucho más, pues venció a la muerte, que por amar tanto el Señor a María y Marta resucitó a Lázaro"... ¡Oh amor, que todo lo puedes, todo lo rindes, todo lo vences! Omnia vincit amor, et nos caedamus amori. Eres el más fuerte, pues no vences ejércitos armados, no sujetas reinos, no ligas las robustas manos de los bravos jayanes; más rindes los corazones humanos, no con hierro y mano armada, más con dulzura, con regalo, con suavidad, con blandura. Eres, joh amor!, lo mejor del cielo y tierra, y lo mejor que Dios puede dar" ${ }^{64}$. Como nos dice el beato Orozco, Cristo cautivó a la mujer cananea, al ciego junto al camino, a los diez leprosos, a la samaritana, a la Magdalena, a todos los que

60. ORozco, Certamen, 366.

61. Ib., 491, nota 18. Y remite el Beato a san Agustín, Trat. 26, n. 4 In Joannem y al comentario al Salmo 90, del mismo, y a san Bernardo en el Cantar de los Cantares, sermón 21 y 22.

62. Ib., 372 .

63. Ib., 373.

64. Malón de Chaide, P., Ib., I, 67. 
le quieran seguir y a toda la humanidad: "Déjase aprisionar nuestro Salvador en el huerto, para podernos él atar con las ligaduras de su amor, y se ofrece voluntariamente cautivo para ir a morir a fin de que en el punto de su ascensión a los cielos pueda llevar consigo a la cautividad (Ef 4,8) libertando del limbo a los antiguos Padres, y llevándolos a todos consigo a la Patria celestial" ${ }^{65}$. Como lo dice san Agustín en la exposición al salmo 149,5: 'Los que gimen en esta vida y desean aquella patria, corran, no con los pies corporales, sino con la caridad; no busquen naves, sino alas: ármense de las dos alas de la caridad. ¿Cuáles son? El amor de Dios y del prójimo!

Con tal suavidad y amor cautiva el Señor del mundo que es desgraciado el que no se deja cautivar y se siente desgraciadamente libre el que huye de esta cárcel de amor. En este amor se enardece el hombre y toda su humanidad. El P. Malón de Chaide expresó de forma entusiasta, también, esta situación respecto de aquellos que Dios tanto ama: "Están rendidos a aquella divina, pura, antiquísima hermosura de Dios; llévalos el amor enlazados y presos de un dulce y libre lazo de amor, para que tornen a la fuente y principio de donde salieron; y como ven aquel son de infinita belleza, amante eterno de sí mismo, vanse aquellas mentes angélicas, atónitas, enajenadas de sí, libres sin libertad, presas sin prisión, como las mariposas a la llama" ${ }^{66}$.

San Agustín nos advierte que Cristo cautiva solamente con la fuerza del Amor, no tiene ninguna otra fuerza. Así se nos asegura en el siguiente pasaje agustiniano, bien conocido de Orozco y del P. Malón de Chaide, donde se nos explica cómo atrae el amor, cómo cautiva y arrastra: "No pienses que te llevan forzado; el espíritu es llevado también por el amor... Si pudo el poeta decir: 'a cada uno le arrastra su placer', no la violencia, sino el placer, no la fuerza, sino la delectación; ¿con cuanta más fuerza diremos que es llevado el hombre a Cristo, puesto que el hombre se goza en la verdad, se goza en la felicidad, se goza en la justicia, se goza en la vida eterna, cosas todas que se resumen en Cristo? ...Dame uno que desee (ame), uno que tenga sed y suspire por la fuente de la eterna patria, dame uno tal, y sabe lo que digo" (In Joan 26,4).

El beato Orozco insiste del mismo modo: "Tráeme en pos de ti (Cantar de los Cantares 1,4). Átame fuertemente con las ligaduras de tu amor, no ya hiriendo mi corazón con el dardo de la caridad, pues que muchos, heridos, suelen huir de la guerra, sino, una vez herido con la saeta de tu amor, asegurándome con las fuertes cadenas de la caridad, de tal suerte, que el amor para contigo no sólo sea insuperable, más también inseparable, no pensando,

65. Orozco, Certamen, 374.

66. MALÓN DE Chaide, P., I, 55. 
ni hablando, ni haciendo cosa alguna, sino en tu presencia, con tu ayuda, y por tu mandado. ¡Oh, si me fuera dado a mí, nisérrimo, cantar gozoso y en acción de gracias, a semejanza de la amada Esposa: Yo le así, y no le dejaré (Cantar 3,4). Esto te pido, esto encarecidamente te ruego" ${ }^{67}$.

También el P. Malón de Chaide há comentado este pasaje, pues con ninguna otra cosa se puede contentar el hombre sino con el amor que le hace divino, uno con Dios. Dice así: "Tenui eum, nec dimittam; ya amigo mío, os he hallado, ya os tengo, yo os prometo de no dejaros porque no os me perdáis, otra vez" ${ }^{68}$. Sólo vivir con Dios es la felicidad infinita y 'habitar en la casa del Señor por años sin término' el sumo deseo.

La caridad cuanto más se vive más se enciende, así que el amor inunda toda la vida de la persona hasta desfallecer de amor, de modo que abraza al alma en todo el amor divino. Así nos dice el Beato: "La tercera señal de la caridad es aún más perfecta y excelente, porque hace que enferme la esposa, herida y ya cautiva. Voz de quien desfallece es aquélla (Cantar, 5,8): "Conjúroos, hijas de Jerusalén, que si halláreis a mi amado le aviséis y digáis que desfallezco de amor" "69. Esta enfermedad es para salud, pues no puede vivir la persona humana de las cosas de este mundo y sólo vive ya para Dios como sumamente amado: "Nada le contenta, nada le satisface sino su único amado; nada endulzará su espíritu, sino gustar a Jesucristo su esposo. A uno solo ama, a uno solo Esposo quiere, de uno está sediento, a solo uno anhela, con exclusión de todos. En este sólo se fortalece, en este solo, a quien llama su Amado, descansa y se sacia" ${ }^{70}$.

Este es el más puro amor en el que sólo Dios es amado, en él se se hace y se sacia el hombre y sólo Dios puede aliviarlo, con su mismo amor. Por eso: "Feliz el alma que cae en la postración por esta tan saludable enfermedad. Anhela a Cristo, su amado Esposo; en él se inflama, y únicamente y en él descansa"... "¡Feliz enfermedad, en virtud de la cual desaparecen todas las indisposiciones del alma! ¡Feliz desfallecimiento, que en sí encierra las innegables señales de salud divina y espiritual. ¿Qué más? Atormentada por esta enfermedad, cuanto más bebe, más sed tiene anhelando con vehemencia acercarse a la fuente viva, Cristo Jesús, según aquello: Los que me beben, sentirán aún sed" ${ }^{71}$.

Aquí ya sólo Cristo es médico y vida del alma, los otros son impostores y matasanos. Descansando en él llega la 'languidez santa'. Ésta es la muerte mística donde 'ya no vivo yo sino que es Cristo quien viven en mí'. Dios es la

67. Orozco, Certamen, 374-375.

68. MALÓn de Chaide, P., II, 252.

69. Orozco, Certamen, 375.

70. Ib., 377.

71. Ib., 378-379. 
vida de la vida, el alma de nuestra alma por la que el hombre se une totalmente a Dios. El alma se abraza con Dios en plena entrega y donación sin fin. Así dice el Cantar: 'La izquierda de Él, bajo mi cabeza, y su derecha me abrazará" (Cantar 2,6), y en otro lugar: 'Mi alma se derritió luego que habló el esposo' (...). "El amor causa éxtasis": ${ }^{72}$. Y deja al ser humano como fuera de sí, de modo que abandona la soberbia, la sabiduría del mundo, el poder y la reputación y desfallece de amor en Dios. Vive, así, en el ardor de plenitud la caridad y con amor infinito de Dios y de los demás. Entonces se ama a Dios con todo el ser, alma, vida y corazón. "La esposa que ama hasta este extremo, hiere al Esposo, le liga y le hace desfallecer pendiente en la Cruz en donde él, vencido por la fuerza del amor que nos tiene, cae exánime y muere entre los brazos de la Cruz. Por lo que la esposa clama con santo atrevimiento: Le tengo y no le dejaré. Tengamos, hermano, nosotros también al amado, ligándolo con gemidos y ruegos; y no le dejemos hasta que consigamos nos dé la bendición de su gracia, aumente ésta y su amor, y se nos muestre a sí mismo a cara descubierta" ${ }^{73}$.

En este mismo nivel, nos dice el P. Malón de Chaide que Dios es la vida de la vida y el alma de nuestra alma: "De suerte que, si habéis de tener vida, ha de ser en Dios. ¿Cómo? ¿entendiéndole? No, sino amándole; porque, como habemos dicho, el amor une al amante con el amado, y hácele comunicar la vida de quien ama, y que el amado sea alma del amante: $\mathrm{Y}$ así, no es una metáfora ni sólo estilo de hablar, cuando al amado le llamamos nuestra vida, nuestra alma" ${ }^{74}$. Entonces es cuando podemos decir con el Apóstol: 'Mihi vivere Christus est: Para mí la vida es Cristo'. Y nos añade el P. Malón de Chaide: Él es nuestra vida, nuestro amor y nuestro descanso: "Así que los santos, porque viven en Dios, le llaman su vida. San Pablo lo dijo bien, como todo lo demás en el capítulo 3 a los Colosenses: Mortui estis, et vita vestra abscondita est cum Christo in Deo. Cum autem Christus apparuerit, vita vestrae, tunc et vos apparebitis cum ipso in gloria”. (...). entonces, dice san Pablo, cuando apareciere, vuestra vida, aparecerá, esto es, se descubrirá y conocerá el mundo que vivíades. Llama a Cristo nuestra vida, porque él nos la da.

De aquí se sigue que, conforme el amor, sube o baja de valor el hombre; porque no es más bueno de cuanto lo fuere la vida, y ésta la da el amor: luego no será más bueno de cuanto lo fuere lo que ama. Por eso dijo mi Padre san Agustín: 'Si tierra amas, tierra eres; si cielo, cielo eres; si Dios, Dios eres'; porque, Qui adhaeret Deo, unus spiritus est cum eo" ${ }^{74}$. Por eso

72. Ib., 380 .

73. Ib., 384.

74. Ib., Malon de Chaide, I, 71. 
también la Escritura dice que quien se aleja de Dios se destruye a sí mismo: 'los que se alejan de ti perecerán'.

Termina el beato Orozco el libro del Certamen del amor Santo con el ejemplo de María, herida de amor cuando se perdió Jesús en el templo, pues se nota aquí su gran caridad: "Véola herida y traspasada con el dardo de amor cuando Jesús, su amado Hijo, siendo de doce años de edad, quedó en Jerusalén, y ella, herida de ardentísimo amor, buscóle con ansias mortales, de tal manera que pasados tres días, como le hallase, sin poder contenerse, ahí, en el templo mismo delante de todos, llevada del afecto materno, exclamó: Hijo, ¿por qué lo has hecho así con nosotros? He ahí que tu padre y yo, angustiados, te buscábamos" (Lucas 2,48). "Ves aquí, ciertamente la violencia del amor y la herida de la caridad que se ocultaban en el corazón de la Virgen, descubierta por esas palabras para que, al correr del tiempo, se manifestase claramente a sus devotos" "25. Lo mismo, cautiva, junto a la Cruz (Jn 19,25) unida a Cristo por la Caridad parece decirnos: "Anunciad a mi amado que estoy enferma de Amor" ${ }^{76}$.

Lo mismo, fuera de sí por el amor, nos dice el Beato, sigue a Cristo resucitado, fatigada y cautiva marcha hacia el monte Olivete (Act 1,9-12). Nuevamente cayendo en éxtasis, desfallece, llegado el santo día de Pentecostés, cuando haciéndose manifiesto el Espíritu Santo, ilumina y purifica los corazones de los discípulos. Y por fin desfallece en la casa de Dios: "Entonces, mucho mejor que David, pudo decir: Mi alma codicia y desfallece en los atrios del Señor. Sigamos las huellas de esta Virgen veneranda; a fin de que, amando a Dios en este certamen del amor santo, venzamos y gloriosamente triunfemos" $" 7$.

Tal es el Certamen del amor Santo, "el certamen del amor suave y lleno de dulzura, en el que herido por caridad, ligado, extenuado y caído por la fuerza del amor en los brazos del divino Esposo, Jesús, te harás superior al mismo Dios, teniéndole aprisionado por la fe viva y sincera, la firme esperanza y el ardiente amor" ${ }^{78}$. Éste es el gozo y la felicidad suprema del hombre en este mundo. Para conseguirla, nos recomienda el Beato con san Agustín, la lectura viva de la Sagrada Escritura y la meditación de la vida de Cristo por la cual le oímos y le amamos. En efecto, Cristo, por nuestro amor se encarnó y se hizo mortal para enseñarnos y darnos la ley del amor y ofrecernos su abrazo de paz por el cual el alma se une con Dios de tal modo que,

75. Orozco, Certamen, 384-385.

76. Ib., 385 .

77. Ib., 386.

78. Ib., 387. 
como dice el Apóstol: "Qui adhaeret Deo, unus spiritus est"” 79. La fuerza de esta caridad es tal que hace incluso lo imposible de modo que como dice el Apóstol: Todo lo puedo en aquel que me conforta. Y la experiencia de Dios da vida y consuelo total al hombre. Así es cómo Dios ha derramado su caridad en nuestros corazones por el Espíritu Santo que se nos ha dado, para que en ella crezcamos en comunión con Dios y con el prójimo ${ }^{80}$. Pero lo importante, no son los gozos y los dones de Dios sino Dios mismo: "Amen las adolescentes tus dones, tus delicias, yo en cambio te amo con todo el corazón, no buscando tanto tus dones como a ti solamente" ${ }^{81}$. También Santo Tomás de Villanueva, insiste en este pensamiento de san Agustín: 'Nolo tua sed te', citado a su vez por Malón de Chaide, como hemos visto ya más arriba (cf. nota 59). Santo Tomás de Villanueva lo dice así: Propter suavitatem, propter dulcedinem, propter unctionem adolescentulae dilexerunt te, ego autem inter cruces, inter labores, inter medias mortes novi diligere te. Quaerant illae dona tua, ego autem te ipsum; quia delectantur in te, quaerunt te; ego autem non tua dona quaero, sed te nudum cupio, te nudum diligo, te nudum adamo" ${ }^{82}$. Ciertamente, son muchos lo que desean gozar de Dios y reinar con Él, pero pocos los que aceptan sufrir con Él; por eso decía san Bernardo: “¡Oh buen Jesús, qué pocos son los que desean seguirte aunque no hay nadie que no quiera ir a ti pues todos saben que tus gozos están contigo siempre, es decir, sin fin! Todos desean gozarte, pero no así imitarte, desean reinar contigo, pero no sufrir contigo" ".3. Sólo el que ama a Cristo más que a todas las cosas podrá encontrar este Dios del amor y conocer sus secretos y misterios, pues sólo el que se entrega totalmente a Dios recibe de Él sus tesoros secretos. Por eso dice el Señor: "Te revelaré los tesoros escondidos y los secretos arcanos. Pues ciertamente los misterios de la encarnación y de la redención, como también los de la creación del mundo, son como el tesoro escondido en el campo de las Santas Escrituras que solamente puede encontrar el que todo lo desprecia por el amor de Dios" ${ }^{84}$. Así la vida del hombre religioso es ya vida en el Cielo, en el Dios del amor y así ama a Dios con todo el corazón. Éste es el momento en que el religioso se introduce incondicionalmente en el océano de Dios. Tal es el amor esponsal que se nos describe en el Cantar de los Cantares, éstas son las bodas de Cris-

79. Orozco, Commentaria q. in Canti. Cant., 5, y también 3 y 4.

80. Ib., 11.

81. Ib., 12: "Diligant adolescentulae tua dona, tuas delitias, ego dumtaxat te toto pectore diligo, non tam quaerens tua dona, sed te solum".

82. Divi Tomae a Villanova, In Cantica Canticorum Commentaria. Opera omnia, vol. VI, . curante I. Monasterio, Manila 1897,16.

83. Orozco, Commentaria q. in C. C., 16.

84. Orozco, Commentaria q. in C. C., 18. 
to y la Iglesia en cada uno de sus fieles. Pero, como nos dice santo Tomás de Villanueva, comentando al Cantar, sólo el Espíritu Santo nos puede abrir el sello de este libro, pues sólo el amor nos puede enseñar este camino del gran amor, y sólo quien lo ha experimentado sabe de qué se trata, pues sólo el que sigue el camino de la vida, frente al mundo vago y errante, conoce y experimenta estos amores de Dios y el alma: "Hos solus novit expertus; sine hac experientia impossibile est sentire quod dicitur; amoris canticum amor percipit; hujus Epithalamii optimus interpres amor est. Denique, sicut Propheta de fide, ita et nos impraesentiarum dicimus de amore: Nisi amaveritis, non intelligetis". (Tomás de Villanueva, In Cantica Canticorum Comentaria, 14,-15). Ésta es la unión del verbo y el alma, ésta es la soledad del desierto donde se oye la voz de amado, donde se encuentra la vida y la fuente de la vida, en dulcísimo coloquio, según nos describe san Agustín en sus Confesiones (libro IX, c. 10), nos recuerda también el mismo santo Tomás de Villanueva. Ésta es la unión por la que Dios habita al hombre en cuerpo y alma y que toda la humanidad puede personalmente gozar con sólo entregarse a Dios. Entonces, nos dice santo Tomás de Villanueva, se convierte en 'el Dios de nuestro corazón y nuestra herencia para siempre' como nos dice el Psalmo 72,26. Así establece Dios en nosotros el orden de la Caridad, el fuego del amor, que no se puede comprar.

San Bernardo, uno de los autores más citados por el beato Orozco tanto en el Comentario al Cantar de los Cantares como en el Certamen del Amor Santo, describe, a su vez, este proceso en sus sermones sobre el Cantar. Se trata de una conformación total del alma con Dios, según la idea agustiniana de que Cristo es nuestra forma y el alma de nuestra formación, a través de su Espíritu Santo que es amor. Dice äsí en el Sermón 83 sobre el Cantar: "Tal conformidad con el Verbo por medio de la caridad engendra en el alma el matrimonio con el Verbo: maritat animam Verbo. Mas, tal matrimonio no se puede verificar sino es en cierta semejanza de naturaleza, la cual es obrada por medio de la voluntad, que ama como ella es amada. Así que si ésta ama de modo perfecto, desposado se ha. Verdaderamente es éste un contrato de matrimonio espiritual y santo. Poco ha dicho con la palabra contrato, porque es verdadero abrazo. Abrazo en todo el sentido de la palabra, en el que hay un querer y no querer, el cual hace de dos espíritus uno". Se trata de una entrega total de Dios al alma y del alma a Dios por el que Dios se convierte en vida de su vida y alma de su alma. Como lo dice el mismo san Bernardo en el sermón 85 sobre el mismo Cantar: "Si observas -dice- que el alma se adhiere con todas sus fuerzas al Verbo, dejadas todas las cosas; si adviertes, que vive toda para el Verbo, que se gobierna toda por el Verbo, que concibe sólo del Verbo lo que ha de parir para el Verbo; si realmente puedes decir 
con verdad: Para mí el vivir es Cristo y el morir una ganancia: piensa entonces que realmente eres Esposa del Verbo" ${ }^{85}$.

Así todo el hombre se engolfa en el mar inmenso e infinito de Dios, pues Dios viene a él y hace su morada en él, y esa presencia de Dios hace al hombre todopoderoso por la fuerza del amor, omnipotente de Dios. El beato Orozco nos recuerda aquí una vez más le experiencia agustiniana: 'Nada hay difícil para el amante, pues el amor de Dios incluso las cosas difíciles e inhumanas las hace fáciles y llevaderas'. El amor de Dios, como la fe, vence al mundo, y convierte la humillación en humildad. Pero como muchas veces, aquél falta, nos dice Alonso de Orozco, muchos 'se ven humillados pero no son humildes'. Pero Dios que consuela a los humildes, les da descanso en la contemplación y en su amor que enardece el corazón y calma la sed del ser humano que toma por bandera el amor. Así el Espíritu Santo crea un nuevo Pentecostés por el que el alma creyente herida ya desfallece de amor de modo que puede decir con el Apóstol: Vivo iam non ego, vivit vero in me Christus: Vivo pero ya no yo sino que es Cristo quien vive en mí. Entonces dejándolo todo, las personas religiosas "siguieron las huellas del Salvador. A esto alude san Agustín cuando dice en sus Confesiones: habías herido mi corazón, Señor, con las flechas de tu caridad" ${ }^{86}$. ¡Ojalá! que también nosotros, nos dice Alonso Orozco, lo vivamos así, pues Cristo sustenta a su Iglesia con su amor, su fe y su esperanza, y ella está enferma de amor de modo que puede decir que 'duerme, en el Señor, mientras el corazón vela' como la Esposa del Cantar. "De lo cual dice san Pablo: Estáis muertos, y vuestra vida está escondida con Cristo en Dios" ${ }^{87}$. Así es como Dios está con nosotros y se nos entrega infinitamente para hacernos suyos porque Cristo amó a su Iglesia hasta darle su vida y así surgió una nueva primavera del amor y de la vida para toda la humanidad cuando tantos renunciando al mundo "vestigia Christi secuti sunt" ${ }^{88}$. Seducidos por el amor se le entregaron cuando él les donó su vida haciendo una sola familia y una misma casa, de una misma sangre, en la que tiene sus complacencias. Entonces Cristo es para la Iglesia y la Iglesia es para Cristo, en cada fiel, que ferviente permanece y ama. Por eso dice el Cantar: Mi amado es para mí y yo para Él. Con estas palabras se muestran el amor mutuo y la verdadera caridad con la que el Esposo ama a la Esposa y ésta ama a su Esposo y que ese amor 'nunca perecerá' ni dismi-

85. San Bernardo es, sin duda, uno de los autores más citados por Alonso de Orozco. Estos textos los hemos tomado de Custodio VeGA, A., Cumbres místicas. Fray Luis de León y san juan de la Cruz. Aguilar, Madrid 1963, 144-145.

86. Orozco, Commentaria C. C., 64.

87. Ib., 72.

88. Ib., 84. 
nuirá, porque 'el amor nunca decae' (1 Cor 13,8). como lo expone santo Tomás de Villanueva: "dilectus meus mihi, et ego illi, qui pascitur inter lilia. Et nihil amplius, o Dilecta? ille tibi, et tu illi, et nihil ultra? utique nihil amplius; nam quod amplius est, ex superfluo est. Solus mihi sufficit, solus abundat, solum volo, solum cupio: quidquid ille non est, egestas mihi est: ille solus mihi, et ego quidem sola, solum illi: Quid mihi est caelo, et a te quid volui super terram? Deus cordis mei, utique pars mea, et sors mea tu, Deus, in aeternum. Beata mens cujus ista sunt verba, quae in veritate dicere potest: Dilectus meus mihi et ego illi" ${ }^{89}$.

Este amor inmarcesible es el que renueva el corazón del hombre y lo llena siempre, por todas las edades, de nueva juventud. $\mathrm{Y}$ es una búsqueda permanente por encima de los propios intereses, por encima del propio yo y por encima de uno mismo hasta aferrarse únicamente el amor, sin poder dejarlo nunca. Tenui eum, nec dimittam. Es una peregrinación constante hacia el Señor del amor hasta habitar realmente en su casa y guardarlo plenamente en el corazón, ya que como nos recuerda el profeta Oseas Dios quiere conducir a la soledad al alma y hablarle al corazón. Santo Tomás de Villanueva nos recuerda que el amor es la fuerza más poderosa de todas, como la gravedad en las piedras, como la savia de la vida, el amor mueve el mundo, y Dios es el amor que incita a todos a amarle y a poner el amor sobre todo para tener siempre a Dios. Y comentando este pasaje del Cantar: Tenui eum, nec dimittam... nos dice: "Nullus enim dubitat, quin tenaciter adhaeserit invento, quae tam anxie prius quaesierat eum; et qui adhaeret Deo, unus spiritus est: quomodo ergo deseret eum, cui sic ex gratia unita est? o charitatis glutinum, quam fortiter ligas! Certus sum, inquit Apostolus, neque mors, neque vita, neque angeli, neque principatus, neque virtutes, neque instantia, neque futura, neque fortitudo, neque altitudo, neque profundum, neque creatura alia poterit nos separare a charitate Dei, quae est in Christo Jesu Domino nostro. Id ipsum ista nunc loquitur: Tenui eum, nec dimittam" ${ }^{0}$.

Por nuestra parte debemos permanecer, estar vigilantes, para entrar con Cristo al banquete de bodas y no convertirnos en vírgenes necias. Así vamos rehaciendo su imagen en nosotros, ya que somos hechura suya, y sólo, igualmente, por su gracia 'somos los que somos', para que su gracia no sea vana en nosotros. Dios es amor y obra de su amor somos. Y puesto que sus delicias es 'estar con los hijos de los hombres' como nos dice la Sabiduría y los Proverbios, debemos vigilar y orar y trabajar para que nuestras delicias no sean otras sino vivir con Él, y llevarle en nuestro corazón, como Él mismo

89. Divi Tomae a Villanova, In Cantica. C. C., 1897, 32.

90. Divi Tomae a Villanova, In Cantica. C. C., 1897, 36 
nos dice: "Ponme como sello en tu corazón y en tu brazo porque fuerte es el amor como la muerte" ${ }^{91}$. Sólo así nuestra vida y nuestro amor será feliz y bello ya en el camino, como lo será un día plenamente en la patria. Esa es la verdadera obra de la contemplación en la que se nos da totalmente a Dios. Y donde comienza a vivir el hombre aquello que gozará eternamente, como nos dice san Agustín ${ }^{92}$. Así es como nada nos separará del amor de Cristo ni la muerte, ni. la vida ni nada de este mundo o de otro. Y el Dios del amor que todo lo transforma, y transfigura los corazones terrenos en celestiales, nos hará encontrar la paz perpetua de la felicidad del amor. Pero todo ello exige humildad, para llegar a la casa de Dios, que es la vida religiosa, y habitar en su morada todos los días de la vida ${ }^{93}$. Sólo así podremos vencer realmente el mal, habitando en la caridad de Dios y alimentando el amor con el Amor. Sólo el amor nos cura verdaderamente de nuestros males y llena nuestra capacidad de amar con el amor 'indeleble' que crea así el Reino del amor. Todo lo demás nos parecerá, entonces, despreciable: omnia arbitratus sum ut stercora, ut Christum lucrifaciam, nos dice el Apóstol y con él Alonso de Orozco que nos asegura: $\mathrm{El}$ amor vence al invencible, el amor vence al Omnipotente y roba su corazón ${ }^{94}$. Pero el Amor nos exige que no amemos lo transitorio porque nos destruirá el corazón, mientras que el amor divino nos divinizará: "Pues, por su misma naturaleza, el amor, según dijimos, transforma al amante en la realidad amada. Por eso dice san Agustín: 'el alma más está donde ama, que donde anima'" ${ }^{95}$. Ésa es la manera como Cristo nos roba el alma y el corazón, y su amor, entre los suyos, es la mejor predicación. Dios nos hiere con su amor y es herido por nuestro amor, como dice el Cantar: Vulnerasti cor meum soror mea, vulnerasti cor meum. Es pues, tan grande la fuerza de la caridad que puede 'herir el corazón de Cristo'. Debemos, pues, amar a Dios, porque él nos amó primero, como nos dice la Escritura. Sin el amor nada vale nada pero con la caridad, fuente de todas las virtudes y gracias y del agua de la vida y de todo amor y de toda paz, el amor de Dios nos contagia y nos llena de fecundidad y de la salud de las fuentes de agua viva. Nos ensancha el corazón, nos embriaga de su dulzura y enardece el corazón con el vino del amor divino mientras nos llama a resurrección ${ }^{96}$.

91. Orozco, Commentaria, 132 y 114-115.

92. NolAN, M., El grito del corazón. Conversión y oración hoy. Roma 1987, 14 y 15. Ahí se dan los textos agustinianos al respecto.

93. Orozco, Commentaria, 151. Como es sabido san Agustín en la carta 130 a Proba dice que no debemos pedir a Dios cosas, sino que: "una sola cosa pido al Señor, eso buscaré, habitar en la casa del Señor todos los días de mi vida".

94. Orozco, Commentaria C. C., 171.

95. Ib., 172. 
Así Dios nos deleita con su amistad y nos convierte en amigos: 'Vosotros sois mis amigos'... 'Os he llamado amigos'. Y nos da el viático de su eucaristía, el sacramento del amor para el camino de la vida, el sacramento de la amistad y la plenitud que hace exclamar el Beato Orozco: "O inestimabilem Christi Jesu erga nos amorem. O ineffabilem regis nostri Charitatem" ${ }^{97}$. Rodeados de los peligros de la vida, nuestro Dios que es amor nos socorre, vive en nosotros y nos une a él, vive en nuestro corazón y lo cuida aunque como dice san Agustín: "El que te hizo sin ti, no te salvará sin ti" ${ }^{98}$. En esto muestra su amor gratuito pues en nada nos necesita. Debemos, pues abrirnos a Dios, porque de Él somos, no nos quedemos fríos ante su amor; antes debemos dejar entrar a Cristo para que viva en nosotros todo su amor, a pesar de los males de este mundo, uedicándonos totalmente a Él preocupados por las cosas del Señor y no por las de este mundo (1Cor 7,34$)^{99}$. Los que no conocen a Dios, sobre todo se preocupan de las cosas mundanas; nosotros debemos, al contrario, ser santos, con una caridad efectiva, ayudando a Cristo en todos, siendo misericordiosos y compasivos con los pobres y necesitados ${ }^{100}$ como Abraham, Job, Tobías; de lo contrario 'habrá un juicio sin misericordia para los que no tuvieron misericordia'. Más la caridad nos invita a alegrarnos con los que se alegran y a llorar con los que lloran.

Debemos desear ardientemente acercarnos a las fuentes de la vida, al Dios vivo y verdadero como el ciervo desea las corrientes de agua viva y de la sabiduría del amor que ama a los que aman y se deja encontrar por los que le buscan; también por 'los más humildes de la tierra'. Por eso le cae a Dios muy bien este nombre del 'Amor' como Dice el P. Malón de Chaide ${ }^{101}, \mathrm{y}$ por eso dice san Ignacio Mártir: "Mi amor, Jesús, fue crucificado". Y san Dionisio nos advierte: "Nadie se turbe con el nombre de Amor, ni le quite del lenguaje de Dios como si fuera indigno de su grandeza; porque los deílocos Padres, esto es lo que hablan de Dios, como son los Profetas y. Santos Apóstoles, por lo mismo toman Amor que Dilección" ${ }^{102}$. Y los antiguos poetas dijeron del amor que era 'antiquísimo, perfecto por sí mismo, prudentísimo y de gran consejo'. La creación entera se convierte siempre a Dios por el amor y deseo de Él. Y el Amor es quien mueve el mundo y por eso es el Alma del mundo. Y san Agustín y otros muchos ya lo identificaron con

96. Ib., 209.

97. Ib., 212.

98. Ib., 218.

99. Ib., 262-263.

100. Ib., 264.

101. Malon De Chaide, O.c. 1959, III, 79.

102. Ib., 81 . 
Dios ${ }^{103}$. Dios por el gran amor que tuvo al mundo le dio a su Hijo único. Y Cristo, presencia del amor supremo, como amase mucho a los suyos 'los amó hasta el extremo'. Y así vemos lo que dijo Orfeo: "el amor se va perfeccionando siempre" ${ }^{104}$. Platón dice: "grande es el Dios del Amor", y maravilloso para los hombres. Y Malón de Chaide nos dice que el gozo de Dios nos llena con su amor, sobre todo por el Sacramento del Amor ${ }^{105}$. San Agustín nos diría que Dios está todo en todos y en todas las cosas: para gobernarlas, sustentarlas, conservarlas, guiarlas, y ampararlas; y todo lo convierte a sí mismo y da a todo la vida. Ciertamente así: "La vida es Dios. Ego sum via, et veritas, et vita: 'Yo, dice el Señor soy la vida' y no hay otra vida sino la suya; luego las cosas en Dios, son el mismo Dios" ${ }^{106}$. Como dice san Pablo: 'el que se allega a Dios, se hace una cosa con él'. Y así nace la comunión de los Santos, al enamorarnos de Dios nos hacemos todos "una sola cosa por amor con él y aún entre sí" ${ }^{107}$. Así se va construyendo la ciudad de Dios, la ciudad del amor que tiene al Dios del Amor por su centro. Es el amor de la Vida que une al amante y al amado, que edifica siempre a los creyentes como piedras vivas, frente a la muerte y el odio que destruyen. Sólo, entonces, nuestra vida está escondida en Cristo y no puede apacentarla la muerte, como ocurre a los malvados (mors depascet eos), pues Cristo nos alimenta con el Sacramento del Amor y de la vida. Él, ciertamente, vino para que tengan vida y la tengan en abundancia (Jn 10,10). Como Él mismo nos dice también: "Mi cuerpo es verdadero manjar y mi sangre es verdadera bebida. El que come mi carne y bebe mi sangre, éste tal está en mí y yo en él. Hasta aquí va diciendo, cómo en este enamorado Sacramento se hace lo que habemos dicho de los dos que se aman, que ninguno de ellos está en sí, sino en el otro. Dice luego: así como me envió mi Padre, que vive, y Yo vivo por mi Padre, así el que me come, vivirá por mí. He aquí como hecha ya aquella unión de amor, el que ama a Dios, vive vida de Dios" ${ }^{108}$.

Tales son los amores y los caminos, por los que Dios se hace vida de nuestra vida, alma de toda alma, amor de todo amor, tesoro de todos los

103. Ib., 88 .

104. Ib., 90 .

105. Ib., 92.

106. Ib., 110 .

107. Ib., 113-114.

108. Ib., 140. Cfr. al respecto Alonso de OROzCO, Opera III, Madrid 1736: Declamatio XIV, In Festo Sacrosancto Corporis Dni. Nostri Jesu Christi: p. 192: "At ubi Verbum caro factum est, sanguinem ejus bibamos oportet, quo vita nostra coelestis, ac divina fit: quia sanguine divino utimur". Pidamos, pues, para que permanezcamos en Cristo y Él en nosotros como nos recomienda san Agustín (ib. 193). Caro mea vere est cibus: "Ésta es la promesa y las arras de su gran amor, por vuestra parte amad a aquel que tanto os amó" (p. 194). El que me come vivirá por mí: "Qui ob Spiritum Jesu vivit, vestigia ejus pro virili sua sectatur". (194). Vivamos su vida. 
tesoros, de modo que quien le tiene posee todo en plenitud de Vida y de Amor ${ }^{109}$. Por lo mismo aquel a quien Dios le falta le falta todo. Es lo que dice el Cantar: "Dilectus meus mihi, et ego illi. Id est, ille mihi opes et deliciae, honor et foelicitas, adeo ut omnia, tanquam stercora arbitrer, ut eum lucri faciam, perpetimque possideam" ${ }^{110}$. Cristo congrega a sí a todos en la familia del amor formado por los 'incipientes', los 'proficientes' y los 'perfectos' o perficientes en abundancia y plenitud de vida, de fraternidad y unidad, en la paz de la caridad verdadera y en el amor de la contemplación divina que nos protege, nos une con su gracia y la vida en el Espíritu en el hogar de la casa de la Iglesia aunque llevamos este gran tesoro y la dulzura del Señor en vasos de barro, y en medio de las tribulaciones, con honestidad, paciencia, caridad y humildad difundiendo en la vida el buen olor de Cristo ${ }^{111} \mathrm{y}$ su amor. Amor, por el cual Cristo tomó la forma de siervo y murió en la cruz, que ahora es nuestra gloria y nuestra bandera, como bien dice el Apóstol: "Nempe in arbore crucis, tum justiciam, tum charitatem, tum denique tolerantiam, et stupendam humilitatem, quis non inveniet" ${ }^{112}$.

Esa cruz de Cristo 'pendiente' es, como dice san Agustín, la cátedra del maestro 'docente' y la escuela de perfección en el amor de la que nos alimentamos cada día en la Eucaristía: "Enim vero, qui fide integra, charitateque flammigera sanctam Eucharistiam adorat, spirituali communione reficitur" ${ }^{113}$. Y como todos los grandes misterios, también éste necesita ser meditado con amor, profunda y constantemente, para asimilarlo y embriagarnos del Amor.

De esta vida de amor, surge la misión hacia todos los pueblos, pues Dios que es amor alimenta y salva a todos los hombres y los llama a la perfección, como lo mandó el Señor. "Praedicabitur Evangelium in toto mundo, et tunc erit consummatio" " ${ }^{114}$. Éstas son las mandrágoras de la fecundidad y el amor, nos dice el beato Orozco; que los apóstoles extendieron por el universo mundo, de modo que Cristo sea todo en todos, e inunde su vida, inflame su amor embriagado de Dios y que se expresa en las obras de la caridad y del servicio del prójimo, pues "en otro caso no diría: lo que hicisteis a uno de estos míos más pequeños, a mí me lo hicisteis" ${ }^{115}$. Entonces también Él se

Comed amigos y embriagaos en el Amor (p. 200), nos recomienda el Beato, entregaos a aquel que tanto se os ha entregado. Según Orozco, la Eucaristía reforma de tal modo nuestra vida que nada deseemos fuera de Dios.

109. MAlon de ChaIDE, oc., 1959, III, 218-219.

110. Orozco, Comentaria C. C., 275.

111. Ib., 315 .

112. Ib., 327.

113. Ib., 329.

114. Ib., 337 y 339 . 
nos dará del todo también a nosotros, se derramará en nosotros, nos confirmará, 'hasta que nos asuma' para estar con Él. En efecto, su gran amor se nos muestra en que cuando aún éramos pecadores Cristo mismo murió por nosotros por eso debemos llevarlo siempre en nuestro corazón y en nuestros brazos glorificando a Dios en nuestro cuerpo, y revistiéndonos de Cristo, por medio de las buenas obras y por su seguimiento. Eso es lo que dice el Cantar: "Ponme como sello en tu corazón y como bandera en tu brazo. "Huc nimirum expectat, quod ore suo sacro dixit: Qui vult venire post me, abneget semetipsum, tollat crucem suam, et sequatur me" ${ }^{116}$. Así también le pedimos al Señor, que murió por nuestro amor, que nos tenga en su corazón para que nunca nos olvide. Él, que dio su vida por nuestra libertad y mostró así que el amor es más fuerte que la muerte, nos pide este gran signo de amor que consiste en amarnos los unos a los otros como Él nos amó. Lo cual, aunque sea difícil, no es pesado ni imposible, pues como dice san Agustín: "Nada hay difícil para el que ama" ${ }^{117}$.

Así, sellada el alma por el amor, se hace fuerte contra toda adversidad y no sólo soporta las tribulaciones sino que se hace muy feliz en ellas como los primeros discípulos estaban alegres de sufrir afrentas por el nombre de Cristo. De este modo, la caridad hace fuertes a los débiles y hasta a los niños y a las mujeres frágiles les hace héroes del amor para asombro del mundo, nos dice el beato Orozco. Por eso Dios da y pide a los suyos un amor incondicional y absoluto, constante y tenaz. San Agustín afirma que a Dios no se le da culto si no es con la caridad, porque el amor es el mandato supremo del Señor, porque el Amor es más fuerte que la muerte y porque el Amor es la medida del amor sin medida y más allá de la muerte. Cristo que murió por amor y resucitó por amor, nos enseña que el amor es más fuerte que la muerte, puesto que ésta separa del cuerpo, pero la caridad separa al hombre del mal. Sólo así muere el hombre de amor, vive por amor y desea morir por amor y unirse a Cristo por amor, como dice el Apóstol: "deseo disolverme y estar con Cristo" ${ }^{118}$.

Es también el amor, 'duro como el infierno', según dice el Cantar, porque quien se ha entregado y unido a Cristo no sufre separarse de Él por nada del mundo. Y por eso dice el Apóstol que ni la muerte, ni la vida ni las más grandes potestades podrán separarnos del Amor de Dios que nos ha mostrado en Cristo Jesús. Este amor es como un fuego que todo lo consume y lo transforma en él a la vez que es algo incombustible; "pues ninguna cala-

115. Ib., 346 .

116. Ib., 357... dicente beato Augustino: "Nihil difficile amanti".

117. Ib., 358.

118. Ib., 360-361. 
midad puede romper la caridad de los hombres piadosos a los que unió el Espíritu con este santo lazo" ${ }^{119}$.

El amor vale más que todo. El hombre lo vende todo y lo entrega todo por el amor. Por eso dice san Agustín: el precio de los bienes materiales es el dinero, pero el precio de la caridad eres tú. El amor es el gran tesoro por el que todo se vende, la perla preciosa por la que se entrega todo. Y desgraciado el que prefiere los bienes de este mundo antes que la caridad ${ }^{120}$. Comparado con el amor el oro es pura arena, y si alguien quisiera comprar el amor con dinero sería todo un despreciable, nos dice el Cantar. Y por eso advierte san Gregorio: "Homo omnem substantiam suam dat pro dilectione, quando quicquid in mundo possidet, pro Christo distribuerit, ut abiiciens, quod impedit, Deum diligat, et terso pulvere solicitudinum, oculos aperiat, Deum optimunque videat, eo acclamante: Beati mundo corde, quoniam ipsi Deum videbunt. Hoc Apostoli fecerunt, qui non solum possesa, set etiam cupita, ut Christum sequerentur reliquerunt. Ecce nos reliquimus omnia (ait Petrus) et sequuti sumus te" ${ }^{121}$.

Entonces, el muro de la caridad es el verdadero fundamento del cristiano y de la Iglesia, la roca sobre la que se edifica, con verdadera seguridad toda la vida creyente; aunque haya desierto y soledad el amor es siempre oasis en el que habita la caridad de la comunidad y donde, como dice san Agustín, encuentra su celestial descanso ${ }^{122}$. Éste es el monte santo del Amor en el que se ha dignado habitar el Señor con los hombres, dándoles los dones y carismas de la felicidad divina: "alioquin ipse non diceret: Ad eum veniemus, et mansionem apud eum faciemus. Iesu bone, et hominum amantissime, quamprimum ad corda nostra venire ne moreris: ubi mansionem fabricans, a nobis, proclivi genu precamur, ne discedas" ${ }^{123}$.

Esta vida de Dios en el hombre es la que hace al hombre divino al transformarlo por el amor.

\section{LOS VOTOS RELIGIOSOS COMO EXPERIENCIA CONCRETA DEL AMOR}

Al tratar de explicar los votos religiosos, sigue el beato Orozco en el mismo tono de vivencia del Amor. La pobreza es el primer ornamento del alma, Esposa de Cristo. Porque no se ha de embellecer la Esposa del Señor

119. Ib., 364 .

120. Ib., 366 .

121. Ib., 367. El beato Orozco utiliza mucho en su comentario a san Gregorio, a Orígenes, a san Jerónimo, a san Bernardo y, por supuesto, a san Agustín.

122. Ib., 381.

123. Ib., 386. 
con los adornos del mundo sino con los del mismo Dios, "y porque él amó la pobreza, la castidad y la obediencia, quiere, que con tales ornamentos se atavíe el alma" ${ }^{124}$. Por la pobreza dedicamos a Dios los bienes exteriores, los bienes puramente materiales, del cuerpo y del espíritu. Cristo alabó a la viuda pobre (Lucas $21,1-4$ ) porque dio todo lo que tenía, es decir confió su vida a Dios, no a los bienes de este mundo. A Dios le agrada la pobreza no tanto por lo que es en sí, sino por el deseo de entregarle todo con amor sin fronteras. Por eso es mejor dejarlo todo por Cristo, según nos dice san Gregorio, que mantener a mil pobres y poseer riquezas, pues es difícil tenerlas y no amarlas, de hecho vemos que el joven rico del Evangelio quiso más tener sus riquezas que seguir a Dios. Cristo quiere corazones libres porque así se hacen capaces de recibir a Dios y su amor.

Es necesario, por tanto, dejarlo todo y no llenar el monasterio de ídolos, pues le agrada a Cristo que todo lo consideremos basura para tenerle a Él por único tesoro. Cristo, para recomendar la pobreza, nos dice Alonso de Orozco, nació pobre, vivió pobre y murió pobre: "Vuestro Esposo vivió tan pobre, que él dijo no tener casa ni heredad, ni aun donde reclinar su cabeza"125. Pero ahora, quiere refugiarse y descansar en nuestro corazón con toda su riqueza divina. Por eso la pobreza es fuente de alegría, porque nos da en plenitud aquél algo divino que toda vida humana espera. Además no tiene ladrones, todos le hacen sitio a la pobreza, duerme segura y camina sin temor; trabaja y come de su sudor, llena de felicidad. Por eso se dice a los pobres, de parte de Cristo: Bienaventurados los pobres porque de ellos es el reino de los cielos. Lo único que Cristo nos pide como dote y como don, para entrar en su casa, es la pobreza evangélica. Porque así como los Levitas no recibieron herencia porque su heredad y 'su posesión era Dios', así debe ser el religioso cuyo lote y heredad es Dios mismo. Y Él debe ser nuestra única riqueza para siempre.

Todo este gran tesoro de Dios, nos exige ser diligentes en la guarda de la pobreza, pues como nos dice el Beato Orozco: “ $\mathrm{O} \mathrm{Oh}$, qué vergüenza recibo, hermana, cuando veo a tantos pobres guardar la profesión que nosotros hicimos, sin haber prometido ellos pobreza" ${ }^{126}$. Por eso hay que ser sencillos, también en alabanzas humanas, austeros, también en el vestido, los libros, en el oratorio, en regalos y privilegios, pues 'lo importante es que el alma esté llena de caridad, y lo de fuera ande como quiera'. Debe contentarse el reli-

124. Orozco, Desposorio Espiritual, 437.

125. Ib., 439.

126. Ib., 439. Como se ve, el problema es muy antiguo. Cfr. al respecto: GuerRA, A., "Hago voto de clase media. En torno a la pobreza religiosa. Revista de Espiritualidad 47 (1988) 295-326. 
gioso con lo que comparte la comunidad. Y exhorta Alonso de Orozco a la pobreza en estos términos: "En todo tened por hermana muy amada a la pobreza, porque ésta ama en vos vuestro Esposo Jesucristo, el cual os dice que tiene en mucho esta virtud, y os la pagará en riquezas eternas en el Cielo" ${ }^{127}$.

Para recomendarnos esta virtud: "Nuestro Dios siendo rico de riquezas eternas e infinitas hízose pobre (según nos avisa san Pablo) para que con su pobreza fuésemos nosotros ricos" ${ }^{128}$. El que ama a las riquezas más que a Dios es un idólatra; pero cada religioso, es hoy de nuevo el joven del Evangelio que, 'cuando halla el tesoro de la pobreza en el campo de la religión', va con mucha alegría, vende todo lo que tiene y 'compra el campo'. Cuando dejamos los bienes de este mundu se recibe gran gozo pues se rompen las ataduras de la avaricia y se adquiere el gran tesoro del corazón que es Dios, el cual no mira tanto lo que dejamos sino lo que deseamos, y al dejarlo todo por tenerle sólo a Él se nos entrega del todo.

Por su parte, la avaricia es la mayor impiedad y mata la caridad. "Con razón san Agustín llama al deseo de riquezas veneno de la caridad. Llámase sabiamente veneno mortífero lo que se agita por despojar de los bienes al prójimo. ¿Y qué otra cosa hace la avaricia, sino reducir al pobre a la mayor miseria, sin compadecerse de nadie. ¿Qué más? Raíz de todos los males, la llama el Apóstol, porque, como de su fuente, nacen del apetito de las riquezas todos los males. ¡Horror! Llega el Apóstol a llamar al avaro idólatra, porque el avaro no se cansa de servir a las riquezas, las codicia con todo ardor, trabaja lo indecible por aumentarlas, no saciándose nunca de ellas, desprecia en su lastimosa ceguera el saludable consejo del divino Maestro: No podéis servir a Dios y a las riquezas, e intenta desmentir a la misma verdad, creyendo en su insensatez ser posible lo que aquélla ha aseverado que no lo es"129.

Moisés derribó el becerro de oro, Cristo destruyó la idolatría de las riquezas, al hacerse pobre, para darnos a Dios, hacernos ricos en Amor y llenar de sus tesoros divinos nuestras vidas: "Todas estas obras de pobreza, que el Señor, por matar el becerro de la avaricia, y destruir la estatua de oro, obró, son las joyas de nuestra alma, y las llamas de amor vivo, que inflaman nuestro corazón, amador de la pobreza, en tanto que se profese y jure con gran solemnidad" (...). "Veis aquí muerto el becerro, y degollado el toro de

127. Ib., 440 .

128. Orozco, Instrucción de religiosos, en Crónica de la Orden, cap. IX, 67, c. 2.

129. Orozco, El Buen combate. Traducción castellana del P. Pedro Lozano. Madrid 1914, 79-80. 
la avaricia" ${ }^{130}$. El religioso deja los bienes de la 'fortuna', "para gustar más libremente la suavidad de Dios en la oración y la contemplación, mientras se entrega a la pobreza" ${ }^{131}$. No es nada extraño que el cristiano haga esto, pues también lo hicieron los filósofos, porque sabían que las virtudes no son compatibles con las riquezas de este mundo, como dice san Jerónimo a Paulino y nos muestra el Evangelio en el caso del joven rico. Pero estas palabras de Cristo, al joven, no fueron en vano, pues multitud de hombres y mujeres, como dice san Agustín, dejaron todo lo que poseían para abrazar la pobreza de la vida religiosa ${ }^{132}$. Todo lo dejaron por seguir a Cristo, como los apóstoles, abandonaron el cuidado de su vida en manos del amor de Dios y así encontraron el gran tesoro "pleno e indeficiente de todas (las) riquezas" ${ }^{133}$.

También la Iglesia nos recuerda esta experiencia evangélica. En efecto, nos insiste en que: "Cristo, siendo rico se hizo pobre por nosotros, para que nosotros fuéramos ricos por su pobreza" (1Cor 8,9). Y en nuestros mismos días nos dice: "la pobreza de Cristo encierra en sí esta infinita riqueza de Dios; ella es más bien su expresión inefable" ${ }^{134}$. Al citar las palabras de Jesús al joven rico se afirma que "en el interior de esta llamada está escondido el testimonio de la infinita riqueza de Dios"..."Cristo, el más pobre, con su muerte en la cruz, es a la vez el que nos enriquece infinitamente con la plenitud de la Vida nueva, mediante la resurrección" ${ }^{135}$. También se nos recuerda, lógicamente, la bienaventuranza de los pobres. El último documento de la Congregación de Religiosos sobre formación, después de citar los lugares clásicos de la pobreza, nos habla de que: "Lo que quizás es nuevo es una vida religiosa que se caracteriza hoy por una particular sensibilidad hacia los pobres y hacia la pobreza en el mundo" ${ }^{136}$. Se insiste en el espíritu de las bienaventuranzas, en el trabajo, en el estudio de la doctrina social de la Iglesia, en el compromiso comunitario y el sentido cristológico de humildad y austeridad. Y se precisa el objetivo del voto: "Todo esto con el fin de centrar su vida en Cristo pobre, contemplado, amado y seguido. Sin esto, la pobreza religiosa, bajo la forma de solidaridad y participación, se vuelve fácilmente ideológica y política. Solamente un corazón pobre, que sigue a Jesucristo

130. Orozco, A. de, Epistola a un religioso. obras, t. II. Madrid 1736, 462.

131. Orozco, A. de, Liber de suavitate Dei, en Opera, t. I, Barcelona 1882, 187.

132. Ib., 188.

133. Orozco, , A. de, El Buen combate, 84 y 82.

134. JuAN PaBlo II, Redemptionis donum, 12.

135. IB., 12.

136. CONGREgACIÓN DE Religiosos, Orientaciones sobre formación, 2.2.1990, 14. 137. Ib., 14. 
pobre, puede ser la fuente de una auténtica solidaridad y de un auténtico desprendimiento" ${ }^{138}$.

El segundo gran ornamento que ha de embellecer a la esposa de Cristo es la joya de la castidad. El beato Orozco fundamenta este voto en 1Cor 7,32ss.: La mujer consagrada se preocupa de las cosas del Señor y se entrega del todo al Señor. Pues como dice san Agustín: "menos ama a Dios el que alguna cosa posee con afición, y no por el mismo Dios', lo cual remedia la pobreza voluntaria; bien así el segundo ornamento del alma, y más precioso que el primero, es la castidad virginal" ${ }^{139}$.

La virtud de la castidad es más difícil de entender a los ojos humanos y sus enemigos nos son más próximos, dice el Beato, pues se valen del propio cuerpo. San Agustín, dice el beato Orozco, nos advierte que el mayor combate del cristiano es el de esta virtud y afirma que es muy difícil de ganar, "más de aquí nace mayor gloria a las almas, que varonilmente pelean, las cuales, favorecidas de su dulce Esposo, Cristo, son bastante para vivir vida angélica en cuerpos humanos" ${ }^{140}$. San Pablo nos llama a este camino de la castidad perfecta, pero lo hace sin imponernos un mandato, sino que nos anima a una cosa noble "pues la Virgen Esposa de Cristo es, tan libre, y tan gran Reina, que en su Corazón no trata de eso en la tierra, sino de su Criador y Redentor que está en el Cielo" ${ }^{141}$. Este tesoro de la castidad es un don que no todos conocen: 'no todos entienden esto' dice el Señor. Cristo mostró gran estima a esta virtud: “ $\mathrm{jOh}$, bienaventurados los limpios de corazón, pues ellos verán a Dios! Dios, purezá infinita es y no se deja ver sino de ojos limpios, y corazón puro. Juntos estaban san Juan y san Pedro, y los otros apóstoles en la navecilla, cuando a ellos vino Cristo resucitado, y solamente le conoció la virginidad: y así san Juan dijo: el Señor es " ${ }^{142}$.

La virginidad es fecunda, los casados pueblan la tierra, los célibes el cielo. No faltará la tentación ni el desierto, ni la soledad de Dios, pero tampoco la gracia pues muy bien sabe el Sabio que 'nadie puede ser continente si Dios no se lo diere de su mano'. Ciertamente "los peligros son muchos, más el favor de Dios es mayor, y la industria, y aviso vale mucho, con la oración, la abstinencia y recogimiento del corazón. Lirio es entre espinas la Esposa de Cristo, (por él así llamada)"... "Tratad, hermana, en vuestra alma las cosas de Dios, pues él os eligió para su Esposa, el cual no os negará su gracia, pues la promete" ${ }^{143}$.

138. Ib., 14

139. Orozco, A. de, Desposorio Espiritual, 440.

140. Ib., 440.

141. Ib., 441.

142. Ib., 441.

143. Ib., 442, 443. Cf. también: Instrucción de Religiosos $69 \mathrm{v}$. y 70. 
El Beato recomienda como apoyos de esta virtud: la oración, la humildad, la templanza en la comida y bebida, el espíritu de sacrificio, el recogimiento y cuidado del corazón y la confianza en Dios más que en sí mismo. Pero no se piense que el Beato era rígido sin más. De hecho recomienda la idea de San Buenaventura de que el religioso de tal manera ha de salir de la comida 'que se halle dispuesto para orar' No se trata de una austeridad, sin más ni más, o de excesos fervorosos sin razón. Comentando él la Regla de san Agustín, nos dice: "Es aquí de notar la gran sabiduría de este santo Doctor, pues no determinó qué ayunos, ni qué abstinencia habíamos de hacer, sino que cada uno mire lo que pudiere llevar, y aquello haga" ${ }^{144}$.

Por otro lado, esta virtud de la castidad, no se aconseja por desprecio del Matrimonio que es un sacramento instituido por el mismo Señor, sino "para que los hombres, ayudados por la gracia divina vivieran esta vida pura y angélica", la vida divina dada al hombre ${ }^{145}$.

La Iglesia nos anima aún hoy del mismo modo a esta vida noble con las mismas palabras del Apóstol: "El apóstol Pablo ha dedicado también a este tema una apropiada reflexión en la primera Carta a los Corintios (1Cor 7,2840). Este consejo está dirigido de modo especial al amor del corazón humano. Pone más de relieve el carácter esponsal de este amor" ${ }^{146}$. Tal amor tiene a Cristo por amor exclusivo, es fuente de fecundidad abundante y "coloca en el centro de su vida efectiva una relación 'más inmediata' (Evangélica Testificatio 13) con Dios por Jesucristo en el Espíritu" ${ }^{147}$. Es algo que afecta a toda la persona y es 'para el bien de toda la persona' y para servir a los demás de corazón: "La castidad libera de una manera especial el corazón del hombre (1Cor 7,32-35) para que arda de amor a Dios y a los hombres" ${ }^{148}$. Por eso mismo ésta no es una virtud puramente funcional, como a veces se ha podido creer, sino que supone inexcusablemente una mística, como nos propone el beato Orozco, sin la cual esta virtud queda en puro garabato, que no signo.

El tercer ornamento de la Esposa de Cristo es la obediencia. Al ofrecer a Dios nuestra voluntad le damos el alma de nuestra vida que es nuestro

144. Orozco, A. de, Breve declaración de la Regla, Manila 1881, 36.

145. San Pablo anima a los Corintios a la castidad, no para tenderles una trampa, sino para dedicarse con más fervor al Señor, no contra el matrimonio: "Haec haud dicta sunt in matrimonii contemptum, non utique, ceu quod Sacramentum est ab eodem Domino institutum; sed quia cum Dei Filius humanitatem nostram assumpserit, et natus de Sancta Virgine Domina nostra, tempus jam erat vitam instituendi magis coelestem, quaequae vitam Angelorum imitaretur in terra, adeo ut homines, divina gratia adjuti, in carne etsi infirma vitam degerent puram, et angelicam": Orozco, A. de, De suavitate Dei, 188.

146. Redemptionis Donum, 11.

147. CONGREGACION, Orientaciones sobre la formación, 2.2.1990, 13. 
mayor bien: "Haec autem Deo integre offertur per obedientiae votum, quod propterea principalius est, quia est de meliori bono, quod possidemus" ${ }^{149}$. También las Sagradas Escrituras dicen ser mejor la obediencia que los sacrificios. La obediencia es la mejor manera de 'andar con el Señor y ser perfecto'. Por desobedecer se le quitó a Saúl el reino. "Porque pecado de encantador; es no querer consentir al mandamiento del Señor, y casi maldad de idolatría no ser obediente" ${ }^{150}$. En efecto, quien no quiere obedecer se constituye a sí mismo en faraón, en origen del mundo, y fácilmente se diviniza la propia voluntad con idolatría de sí mismo. Por eso dice san Gregorio que la obediencia es la madre de todas las virtudes. Por el holocausto de la obediencia nos entregamos a Dios, no ya nuestras cosas sino nosotros mismos. El camino de la obediencia es el camino de la fe incondicional como vemos por Abraham, padre de los creyentes. Su premio es la felicidad y la alegría perfecta: "Contento grande sentiréis en la obediencia; gusto admirable os dará vuestro Esposo en la subjeción; y creed, que el que de piedra dura dio agua suave a su pueblo en el desierto, dará gran recreación a vuestra alma en la aspereza, y martirio, que es negar la propia voluntad" ${ }^{151}$.

La obediencia incondicional es la afición incondicional por Dios y por la vida religiosa que nos libera de toda esclavitud y pecado, pues: adonde hay Espíritu, hay libertad. La desobediencia es el origen de todos los males: "No hay alma tan señora y tan libre en Religión, como la que perfectamente obedece; ni tan cautiva, en tierra de moros aherrojada, como la que no sabe obedecer: hace lo que quiere, y anda por donde le parece, vagueando como Caín, distraída, desasosegada, e inquieta, como el malaventurado Satán" ${ }^{152}$.

Sin la obediencia, de nada valen los sacrificios y ayunos: En vuestros ayunos está vuestra voluntad, denuncia el profeta Isaías (58,1-14). Con estos hombres no trata Dios, en amor, ni viven la caridad de la vida en Religión: "Avísoos, que estáis en tierra santa, y entre gente santa: quitad, como mandó Dios a Moisés, los zapatos de los pies del alma: dejad esos deseos del siglo: renunciad a vuestros apetitos mortíferos, que va la vida en ello. De otra manera no os hablará Dios desde la zarza que arde, y no se quema, que es la Religión, de caridad inflamada, cuyas espinas son ayunos, disciplinas, cilicios, oraciones, y todo lo demás. ¡Oh triste de la Esposa de Cristo Jesús, Salvador nuestro, y Redentor, a quien él no habla! Desventurada el alma, que no oye su dulce coloquio dentro de su corazón" ${ }^{153}$.

149. OROzCO, Liber de Suavitate Dei, 189.

150. Orozco, Desposorio Espiritual, 443.

151. Ib., 443-444.

152. Ib., 444.

153. Ib., 444. 
En cuanto a los grados fundamentales de la obediencia, los divide el Beato así: $1^{\circ}$ obedecer; $2^{\circ}$ obedecer con prontitud; y $3^{\circ}$ obedecer con humildad. El cuarto grado es obedecer hasta la muerte ${ }^{154}$ perseverando hasta la consumación.

La obediencia es una virtud varonil, pues no hay mayor fortaleza que vencer la propia voluntad, lo que es también gran dulzura, pues nos trae la paz al corazón. Dichoso el que con Cristo puede decir: "Consumatum est. todo es acabado, que en nada resiste, ni contradice la santa obediencia, la cual vale más, y lo tiene Dios en más, que todos los sacrificios, y holocaustos de obras santas, que le podemos ofrecer" ${ }^{155 .}$

Para ser perfecto, el religioso debe obedecer con humildad, en otro caso, su estancia en el monasterio es inútil y vacía, "o por mejor decir siempre irá desaprovechando, cuanto más quiere ser exento y muy puesto en su parecer" ${ }^{156}$.

Obedecer con miramientos y no obedecer, en las cosas pequeñas, nos lleva a desobedecer en cosas más importantes porque el que no es grande en lo pequeño tampoco lo es en lo grande. Nuestra negación y nuestra muerte en la obediencia es sólo nuestra muerte del hombre animal no del hombre nuevo y verdadero, por eso nos trae mayor felicidad pues nos vive en el amor: "Nuestra voluntad más libre queda en Jesucristo, sujetándola por su amor"... "y queda con la vida"... "y con esto queda muy contento Dios, el cual conserva la libertad y vida del espíritu por la obediencia" ${ }^{157}$.

La obediencia es el alimento de nuestra vida religiosa, como fue el alimento de Cristo hacer la voluntad del Padre: "El cuerpo sin comer anda flaco y desmayado y no puede vivir, así el ánima que no sabe obedecer está enferma y con el gran desmayo cae y tropieza muchas veces pecando" ${ }^{158}$. La obediencia embellece todas las virtudes y trae su mérito de la primera entre-' ga y profesión que hicimos a Cristo para seguirle e imitarle.

La desobediencia fue el pecado original y la obediencia de Cristo el origen de nuestra salvación, nos recuerda también hoy la Iglesia, que nos invita de nuevo a "seguir a Cristo, que... redimió y santificó por la obediencia hasta la muerte de Cruz (Perfectae Caritatis, 1)" 159. La tendencia egoísta a dominar y a no servir está en el corazón del pecado, mientras la virtud de la obediencia nos lleva a hacer la voluntad del Padre. De aquí brota una disponibi-

154. Ib., 445.

155. Ib., 446.

156. OROzCO, Instrucción de Religiosos, $71 \mathrm{v}$.

157. Ib., 72.

158. Ib., $72 \mathrm{~V}$.

159. Redemptionis Donum, 13. 
lidad total al Espíritu que a su vez "es una particular expresión de la libertad interior, como una definitiva expresión de la libertad de Cristo fue su obediencia 'hasta la muerte': 'Yo doy mi vida para tomarla de nuevo. Nadie me la quita, soy yo quien la doy de mí mismo' (Jn 10,17-18)" ${ }^{160}$. La obediencia, asumida con fe y con amor, acrecienta la libertad de los hijos de Dios ${ }^{161}$. Esto mismo nos dice el beato Orozco comentando el final de la Regla de san Agustín: "Mirad muy bien, dice pues ahora Nuestro Padre San Agustín: mirad, hijos, que no sea vuestra religión por fuerza, no sea servicio de esclavos, sino que sirváis a Jesucristo con libertad y amor, amándole filialmente, y no temiéndole a manera de siervos" ${ }^{162}$. También hoy nos insiste la Iglesia en este fundamento cristológico: "La educación para la obediencia religiosa se hará, pues, con toda la lucidez y exactitud requerida para no desviarse de el 'camino' que es Cristo en misión" ${ }^{163}$.

\section{El PREMIO DEL AMOR ES EL AMOR}

Solamente los humildes y sencillos pueden conocer el gran tesoro del desposorio espiritual y el gran valor de su fidelidad, fecundidad y perseverancia: "En los desposorios comunes tres bienes señalan los santos Doctores, y son éstos: la fidelidad y fruto de bendición, y unidad de por vida, que llaman sacramento. Estos tres tesoros, hermana, hallaréis en el Desposorio espiritual muy más excelentemente cumplidos" 164 .

En cuanto a la fidelidad se centra en el cuidado del corazón, de la lengua y de las obras. Dios mira, sobre todo, al corazón, en todo. Él es un Dios celoso y vela y cela con gran arte a sus Esposas y las está mirando, y cuida de sus amantes siempre en su corazón, "por tanto guardad con cuidado vuestro corazón, porque de él nace la vida espiritual o la muerte"... "vuestro corazón, para ser vos fiel Esposa de Cristo, ha de ser como el Arca del Testamento, que estaba dorada con oro fino de dentro, y de fuera. Ha de ser lleno de amor de Dios, que es oro de altos quilates, y no ocupado en vanidades del mundo, ni de la sensualidad pestífera y mala" ${ }^{165}$.

En cuanto a la guarda de la lengua y su cuidado nos dice el Beato: si el Apóstol Santiago dice a los creyentes que es vana la Religión del que no refrena su lengua, iqué habrá que decir del religioso! Es gran responsabilidad la palabra ociosa, por eso nuestro Beato nos invita a la oración y al diá-

160. Ib., 13 .

161. Congregacion de Religioso, Orientaciones, 2.2.1990,15.

162. Orozco, Breve declaración de la Regla de N.P.S. Agustín, 120.

163. Congregacion, Orientaciones, 2.2.1990,15.

164. Orozco, Desposorio Espiritual, 446.

165. Ib., 447 . 
logo con Cristo que nos hará felices y más felices que toda compañía humana. Nos recomienda así el silencio y el recogimiento santo, pues 'en el silencio y la esperanza está nuestra fortaleza', según la Escritura. Cristo fue gran amante del silencio, nos dice el Beato. Y la vida religiosa la cimienta en el silencio de la contemplación y en el trabajo de la acción, ofrecido a Dios: María y Marta. En cuanto a ésta, nos dice Alonso de Orozco con la tradición agustiniana: "Nuestro Bienaventurado Padre San Agustín dice, que todo el universo nos da lección para que aborrezcamos la ociosidad, porque de estar ocioso, viene gran daño: pues los elementos no están un momento ociosos, los cielos siempre se mueven, y las plantas producen sus frutos; sólo un monstruo hay en el mundo, y es el hombre ocioso y vagabundo" ${ }^{166}$. Así cada uno comerá el pan del propio trabajo y podrá sentarse a la Mesa de Cristo.

El segundo tesoro del Desposorio Espiritual es el fruto de bendición o la fecundidad. Al cumplir la voluntad del Padre, nos hacemos hermanos, hermanas, y madres de Cristo. Y así "será cada una hermana de Jesucristo, a quien con amor regalado solemos amar; a cuya causa en los Cánticos es muchas veces llamada el alma hermana, con quien el Esposo, y fiel hermano Cristo desea partir la herencia que con su sagrada sangre nos ganó, muriendo en la Cruz. Y lo que es más de estimar, que no se contenta con llamar al alma, que le ama, y sirve, hermano y hermana, sino que la llama madre" ${ }^{167}$.

Así Cristo quiso tener muchas madres para ser engendrado en el corazón de los hombres, como dice san Pablo: "Oh hermanos, qué dolores me costáis, hasta que en vosotros se forme Cristo (Gálatas 5,19)". El Papa Juan Pablo II, nos ha recordado recientemente esta doctrina (Mulieris dignitatem, 22), que conserva hoy toda su actualidad. Así el Desposorio espiritual no es estéril vida, sino fecundo gozo de una fecundidad suprema como ya hemos recordado más arriba. Así las personas vírgenes tienen muchos hijos de su amor a Dios, incondicional y absoluto, con honra y honestidad, y recogen abundantes frutos del vergel de sus bodas entrañables. Tales son las buenas obras, fecundas, de la Esposa, la Iglesia que engendra siempre nuevos hijos del Amor, hermoso y sin fronteras, nacidos de la preciosa sangre de Cristo que nos llamó "para que tales flores y frutos diesen. Estimad mucho hermana, este tesoro tan grande; mirad que sois Esposa, hermana, y madre de Cristo; no perdáis tal dignidad por algún descuido, sino cumplid la voluntad del Padre Celestial, la cual declara san Pablo ser, no otra, sino nuestra santificación: que seamos santos, y puros, pues él es Santo, y Pureza infinita" ${ }^{168}$.

166. Ib., 448.

167. Ib., 449.

168. Ib., 450 . 
Finalmente el Desposorio Espiritual es un gran sacramento entre Cristo y la Iglesia: "Gran sacramento es éste, en Cristo, digo, y en su Iglesia. El tercero, y admirable tesoro, que hay en este Desposorio espiritual, es sacramento. Éste es un sagrado secreto de unidad entre la Esposa, y el Esposo" ${ }^{169}$. Es muy útil acercarse al Señor, dice el salmista. Y san Agustín nos recuerda que caminamos hacia el Señor por el amor, 'amando no andando'. Y el beato Orozco nos confirma: "Así como el cuerpo se allega al lugar, que va, andando; así el alma se hace una con Dios, amando, no por más entender, sino por más amar, nos llegamos a nuestro Criador; pues dice ahora el Rey David: gran tesoro es para mí hacerme uno con mi Señor y Criador" ${ }^{170}$. Esto es lo que nos dice san Pablo: ser unos con Cristo, pues el que se acerca al Señor se hace una sola cosa con Él, y que así 'vuestra vida está escondida con Cristo en Dios' (Col 3,3). De modo que 'ya no vivo yo sino que es Cristo quien vive en mí'. Todo lo cual nos lleva a una profunda unidad de vida, como ya hemos visto en diversas ocasiones, por el amor. Además el beato Alonso de Orozco nos recuerda también que donde está nuestro tesoro, allí está nuestro corazón: "Nuestro tesoro es lo que estimamos más que a todo; y si a Cristo hemos ofrecido nuestro amor de todo corazón, y fuerzas, como él le pide, casi sin mirar en ello, hallaremos nuestro corazón en sus manos y presencia"... "No criatura alguna, ni todas juntas le merecen sino sólo el que crió vuestra alma para Esposa suya, porque con fidelidad le sirviese, hecha un espíritu con él" ${ }^{171}$.

Para vivir este amor, en las diversas tareas y momentos de la vida religiosa, hay que llevar a Cristo en el corazón y en la acción, Marta y María a la vez. Como dice el Cantar: "Pone me ut signaculum super cor tuum, ut signaculum super brachium tuum. Ponme, alma, dice nuestro Dios, como señal, o blanco (sello), sobre tu corazón, y también sobre tu brazo... Por el corazón se entiende la vida contemplativa, y por el brazo la vida activa. Éstas son María, y Marta, discípulas amadas de Jesucristo, que en la Religión le sirven cada día" 172 .

No es posible ser tibios en la acción, nos dice el Beato, si se trae siempre presente a Dios a quien servimos con nuestras obras. Esto se debe tener en cuenta, primeramente en la oración que se hace, en los distintos momentos del día, en el coro. Ahí estamos ante el Santo. Alonso de Orozco ofrece aquí

169. Ib., 450.

170. Ib., 450 .

171. Ib., 451.

172. Ib., 451. Esta doctrina es muy agustiniana también y está ampliamente difundida: Cfr. VEGA, J., La vocación agustiniana. El proyecto filosófico-monástico-sacerdotal de san Agustín. Estudio Agustiniano, Valladolid 1987, 465-513. 
pequeños métodos de contemplación y composición de lugar para cada una de las horas canónicas referidos a la Pasión de Cristo que ya expuso en Vergel de oración. Lo fundamental es: "Tened gran aviso, que allí no se aparte Cristo de vuestro corazón, porque sería traición muy grande estar el cuerpo en el coro, y el corazón en el siglo. Oh, plegue a Dios que no se nos diga lo que Cristo dijo a los fariseos y sacerdotes: ¡Este mi pueblo me alaba con la boca, y su corazón está muy lejos de mí!" ${ }^{173}$.

En el capítulo (de renovación, como diríamos hoy) hay que proceder también con gran amor y humildad, sin excusarnos, pues Cristo no respondió a sus acusadores. No se ha de proceder con resentimiento sino con sencillez que por eso le llama Cristo a la esposa 'paloma'. Además, hay que saber excusar las culpas ajenas y acusar las propias. Y nos recomienda el Beato tener por más hermana a quien nos acusa en el capítulo.

También en la mesa debe el religioso proceder con amor; mientras come el manjar corporal los oídos deben desear oír la palabra de Dios, gustándola con dulzura, como dice san Agustín. Hay que dar gracias a Dios por los alimentos, pues 'ya comáis, ya bebáis, nos dice el Apóstol, hacedlo todo para gloria de Dios'. Así debemos recordar la mesa de la amistad y del Jueves Santo, el gran sacramento del Amor, la Eucaristía, y la mesa Pascual que recuerda la Cruz de Cristo y el dolor de su Madre. Eso nos evitará la crítica y la charlatanería vana. En cuanto al comer se ha de proceder así: "No seáis extremada en comer poco, ni de más, sino tasad vuestra abstinencia, con lo que pueden vuestras fuerzas"... y "jamás faltéis de comunidad, sino por enfermedad que a esto compela" ${ }^{174}$.

En el dormitorio, también se ha de llevar a Cristo en el corazón. Aquí perdemos la memoria y todas las facultades. Por eso se ha de dormir encomendados a Dios y sólo el tiempo necesario. Cristo está cerca de nosotros aquí también: 'yo duermo pero mi corazón vela', y se fija siempre en "cómo le ponemos sobre nuestro brazo, encaminando nuestra vida para su honra y gloria" ${ }^{175}$.

Enseña también el beato Orozco sobre cómo se debe examinar la conciencia para mantener el fervor del amor en la persona religiosa. Se ha de mirar por una conciencia pura, pues todo pecado afea la vida de la Esposa. No se debe olvidar que el despreciar lo pequeño lleva a caer poco a poco en lo grande y enfría la vida del amor: "¡Oh hermana, si bien miramos, cuánto consuelo perdemos, a causa de tener en poco las culpas veniales cotidia-

173. OROZCO, Desposorio Espiritual, 452.

174. Ib., 453 .

175. Ib., 454 . 
nas!" ${ }^{176}$. Como nos dice san Pablo: Todo me es lícito, pero no todo me conviene (1Cor 10,23) ni todo me edifica. el Beato remite al 'Examen de la conciencia que pocos días ha envié a esa ciudad de Toledo'. En él se repasan los pecados mortales, para las confesiones generales, y se enseña a confesar las faltas de pensamiento, palabra, y obra. Aquí dirá sólo 'dos cosas en breve'. Recomienda el Beato la confesión frecuente, y también aconseja que la confesión sea breve y clara, sin escrúpulo ni fárrago. Basta acusarse así: Del poco amor de Dios, de la atención en la oración y la eucaristía, de las faltas a los votos, de la humildad y paciencia en sus faltas, del cuidado de los sentidos y de la guarda de la lengua. Se termina con un arrepentimiento general sobre pensamientos, palabras y obras.

En cuanto a la comunión, avisa el Beato de reposar confiado en Dios y no dar lugar ni pábulo a pensamientos sobre pecados y faltas que pudieran inquietar esa comunión con el Señor del amor. Recuerda que ése es un momento de pedir a Dios grandes cosas, sobre todo las virtudes teologales y cardinales, y recibir los grandes dones de su amor, junto con él mismo: "Tales joyas le demandad humildemente, hermana, porque os haga gran sierva suya, y os dé favor para cumplir este Desposorio espiritual" ${ }^{177 .}$

Para terminar esta obra del Desposorio Espiritual, nos habla el beato Orozco del gran premio que Dios dará a los que vivan este gran amor. Primero recuerda el Cantar que dice: ¡Ven del Líbano, hermana mía, ven del Monte Líbano, y serás coronada de Gloria! Esta voz se dirige a todo creyente, nos dice el Beato. En efecto, a todos nos hizo Dios a su imagen y semejanza y por eso llama a toda persona 'hermana'. Veamos cómo describe Alonso de Orozco esta imagen y semejanza: "Dios es espíritu, e hizo el alma espíritu, Dios entiende, diole entendimiento, Dios es libre, y tiene voluntad, dio al alma, que sea libre, y tenga voluntad. Luego bien la llama hermana, declarando su nobleza por naturaleza. Esto es lo que san Pablo alegó de aquel sabio poeta, diciendo: Linaje somos de Dios, por eso no debemos amar el oro, ni la plata, ni las piedras preciosas (At 17,28-29)" ${ }^{178}$. Siendo tan de Dios, a Él sólo debemos amar para vivir con Él eternamente. Esto que se dice a 'cada amigo suyo', nos dice el beato Orozco y que viene muy bien para terminar el Desposorio Espiritual, se ha de entender especialmente de la persona consagrada a Dios en la vida religiosa. Pues el Monte Líbano, tan blanco, es como la vida Religiosa vivida en la pureza, aunque ésta sólo en los ángeles y no en los hombres, nosotros, sea cosa natural. Por eso san Pablo no 
nos pide la castidad consagrada como un mandato sino que nos invita a ella como cosa noble, como un camino muy grande para dedicarnos de lleno, en plenitud, el amor de Dios: "Monte encumbrado es, y por ser tan dificultoso de subir, dice san Pablo, que no osa dar precepto, sino que lo aconseja al que quisiere (1Cor 7,25)" ${ }^{179}$.

Compara también el beato Orozco la vida religiosa al martirio, según es doctrina tradicional, como entrega y oblación totale incondicional de toda la vida a Dios como holocausto de amor y testimonio absoluto. Y dice que esta vida es "Vergel de flores, y azucenas, adonde dice la Esposa, que el Esposo Cristo desciende, para mirarse y recrearse en él" ${ }^{180}$.

Finalmente, la corona de esta vida del amor es el cielo del Amor que ni los oídos oyeron, ni los ojos del hombre vieron nunca una cosa igual "ni al corazón del hombre subió, el premio que dará el Señor a sus amigos (1Cor 2,9). Notad, que para los amadores se guarda aquella bienaventuranza, porque a la caridad corresponde la gloria esencial, y no a la perfección de estado. Quiero decir que si una casada, con mayor amor de Dios, que una religiosa, cumple la ley, tendrá mayor gloria que la religiosa" " ${ }^{181}$. Son la caridad y el amor los que son dignos del Reino de Dios y producen verdaderos frutos de gloria. Se trata de una doctrina muy agustiniana expuesta claramente por san Agustín en el De sancta Virginitate. Es Dios mismo, por fin, la paz, la felicidad, el descanso y la saciedad y la hartura del hombre y no cosa humana alguna. "¡Qué bien dijo nuestro Padre San Agustín, que la vida del cuerpo es el alma, y la vida bienaventurada del alma es Dios, el cual, como es universal bien, da contento a nuestra voluntad; es verdadera sabiduría, y quieta nuestro entendimiento, es Liberal, y Magnífico, para eso se da en perpetua posesión y heredad a los bienaventurados, de manera, que en ver aquellà hermosura infinita, y en amar aquella suma Bondad, y en poseer por herencia eterna aquel tesoro de infinitas riquezas, consiste el premio de nuestros pequeñuelos trabajos" ${ }^{182}$.

Ésta es la Ciudad de Dios que descubre san Juan, y ha glorificado san Agustín, cuyos fundamentos, edificios, fuentes y plazas son grandes joyas y esmeraldas. Y, en cuanto a sus iglesias y religión nos dice san Juan: "No hay en tí Templo, porque Dios es casa de sus amigos, no hay sol, porque el mismo Dios, Claridad infinita, te alumbra; y la lámpara resplandeciente tuya es el Cordero sin mácula, Jesucristo nuestro Redentor (Ap 21,10-25)" ${ }^{183}$.

179. Ib., 457.

180. Ib., 457.

181. Ib., 457.

182. Ib., 457 .

183. Ib., 458. 
El oficio de estos ciudadanos es contemplar y amar aquella bondad y hermosura inefable de la Trinidad de Amor. Esta nueva Jerusalén es nuestra madre y puerto seguro, libre de trabajos, lágrimas, tributos y temores, "desde acá lejos te saludamos, desde este valle de miserias lleno, te bendecimos, y deseamos gozar" ${ }^{184}$.

El beato Orozco termina por decir que no se puede expresar sino toscamente esta gloria que Dios dará a los suyos, a todos los que de corazón le aman, y anima al alma religiosa a dar gracias a Dios como él mismo escribió en el Tratado de la Gratitud cristiana. Y nos impulsa a contemplar sin descanso ý a vivir enamorados esta historia de Amor que es la vida religiosa: "Contemplad muchas veces estas pncas palabras, que el Señor os dará a gustar cosas grandes, que ni yo las sé decir, ni sentir. Sed leal Esposa de este Señor, siendo acabada religiosa, porque cumpla él su palabra, dándoos en pago de la pobreza voluntaria, riquezas celestiales, en lugar de la castidad virginal, la joya de la inmortalidad perpetua, y finalmente, por la santa subjeción y obediencia, la corona del Reyno celestial para ser Reyna y Señora de Gloria eterna. Amén" ${ }^{185}$.

\section{CONCLUSIÓN}

La experiencia del Desposorio espiritual y su ejemplarización en el Cantar de los Cantares, como Vademecum para Amantes, tiene aún hoy una resonancia espiritual y humana de valor inagotable. Un teólogo, tan comprometido en sus días, como lo fue H. Gollwitzer, escribió al final de su vida un librito testimonio, al respecto, que es todo un tesoro, precioso, de una fuente inagotable de vida y amor ${ }^{186}$, eternos. En efecto, la experiencia mística es un momento supremo de la historia humana y su capacidad de amor, de vida y de futuro. Por lo que hace a la mística española, como ha dicho Ciorán, se trata de un "momento divino de la historia humana" ${ }^{187}$.

Dentro de este gran volcán del amor divino y humano, el corazón agustiniano llamea, con propia antorcha, eterna e inextinguible, de un amor siempre presente en todas las generaciones. El caso del beato Orozco, expuesto por nosotros, no ha hecho nada más que confirmar ampliamente esta tradición incombustible a través de todos los siglos. Maestros o compañeros de Alonso de Orozco como Tomás de Villanueva, Agustín Antolínez o Malón

184. Ib., 458.

185. Ib., 458:

186. Gollwitzer, H., Das hohe Lied der Liebe. Kösel, München 1978.

187. Citado por JimENEZ, J. D., Los senderos olvidados de la filosofía. Una aproximación al pensamiento de María Zambrano. Religión y Cultura, Madrid 1991, 37. 
de Chaide, entre otros, acercan la antorcha ardiente, con paso definitivo y firme, a las nuevas generaciones.

Para darnos cuenta hasta qué punto la enseñanza agustiniana del corazón, envuelto en llamas de amor, ha estado en las más altas montañas de las cumbres místicas, bastará citar la anécdota de que el Dr. Jean Krynen, tras graves estudios filológicos, se atrevió a atribuir la versión $B$ del Cántico Espiritual de san Juan de la Cruz, a la inspiración del P. Antolínez, gran comentarista agustino del místico de los místicos. Esta teoría ha sido, felizmente, desmentida en el reciente congreso sanjuanista de Roma con pruebas documentales ${ }^{188}$. Pero este hecho no debe llevarnos a olvidar con quienes caminaban, y se emparentaban, nuestros clásicos, ni disminuye en lo más mínimo el supremo valor del precioso comentario del P. Antolínez al Cántico Espiritual de san Juan de la Cruz, que el Carmelo ha saboreado, junto al del santo, durante siglos ${ }^{189}$. Pero, sobre esto, ya volveremos, en otra ocasión, si Dios quiere.

Domingo NATAL Álvarez

188. Mientras llegan las Actas del Congreso, puede verse: García VAldECASAS, J.G., ¿A dónde te escondiste? Un nuevo e importante manuscrito de san Juan de la Cruz, ABC, literario, 4.5, 1991, VIII; y también: PACHO, E. Cántico espiritual definitivo. Ib., IX y X.

189. antolf́nez, A. Amores de Dios y el alma. Introducción, texto y notas de P. A. Custodio Vega. El Escorial, Madrid 1956. Recientemente ha estudiado al P. Antolínez: GoNZÁLEZ MARcos, I., "Datos para una biografía de Agustín Antolínez, Revista Agüstiniana 30 (1989) 101141. 